\title{
REGIONALIZATION OF IMMIGRANT SETTLEMENT IN ONTARIO: EXPLORING EXPERIENCES OF SMALL AND MEDIUM SIZED RECEPTION CENTRES
}

by

Hannah Goodbrand, BA, University of Guelph, 2015

A Major Research Paper

presented to Ryerson University

in partial fulfillment of the requirements for the degree of

Master of Arts

in the Program of

Immigration and Settlement Studies

Toronto, Ontario, Canada, 2016

(C) Hannah Goodbrand 2016 


\section{AUTHOR'S DECLARATION FOR ELECTRONIC SUBMISSION OF A MAJOR RESEARCH PAPER (MRP)}

I hereby declare that I am the sole author of this MRP. This is a true copy of the MRP, including any required final revisions.

I authorize Ryerson University to lend this MRP to other institutions or individuals for the purpose of scholarly research.

I further authorize Ryerson University to reproduce this MRP by photocopying or by other means, in total or in part, at the request of other institutions or individuals for the purpose of scholarly research.

I understand that my MRP may be made electronically available to the public.

Hannah Goodbrand 


\title{
REGIONALIZATION OF IMMIGRANT SETTLEMENT IN ONTARIO: EXPLORING EXPERIENCES OF SMALL AND MEDIUM SIZED RECEPTION CENTERS
}

\author{
Hannah Goodbrand \\ Master of Arts 2016 \\ Immigration and Settlement Studies \\ Ryerson University
}

\begin{abstract}
This paper explores the regionalization of immigrant settlement in Canada's smaller cities which has not been sufficiently addressed in Canada's largest province, Ontario. The paper investigates this through a comprehensive review of the existing Canadian literature and research into the changing volume of immigrant settlement and the social geography of Ontario's smaller cities from 1996 to 2015. This research is conducted through the development of a categorization system which orders Ontario's CMAs into tiers based on total immigrant population. Two tiers are then compared to reveal any general trends or anomalies which could contribute to the understanding of regionalization in Ontario. A lack of evidence for significant regionalization was found, however, growth in the visible minority populations of some CMAs suggested the development of new international migration pathways. The findings of this paper reaffirm the need for further research in immigrant settlement in smaller Canadian cities.
\end{abstract}

Keywords: immigrants; regionalization; diversity; Ontario; settlement experience; smaller cities. 


\section{Acknowledgements}

I would first like to thank my Major Research Paper Supervisor on this project, Sutama Ghosh, for all of her guidance and support throughout the MRP process.

I would like to thank my parents, Charles and Marlene Goodbrand, for their constant support throughout my life. Without you I never have even finished my application for this program. You have given me the confidence, motivation, and food that I needed to complete this project. I will never be able to appreciate you enough.

I would also like to thank Elliott for your patience with me while I worked on this project.

Lastly, I would like to thank the cohort, my professors, and the friends I have made along the way for making the Immigration and Settlement Studies program a life changing experience for me. 


\section{Table of Contents}

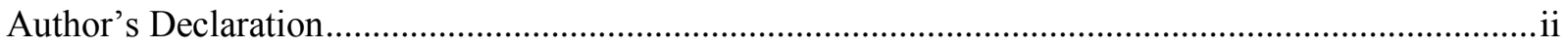

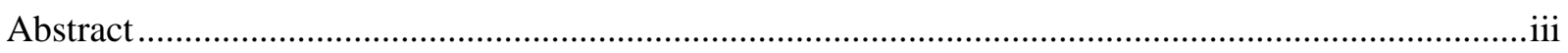

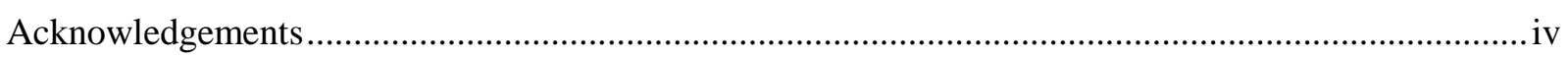

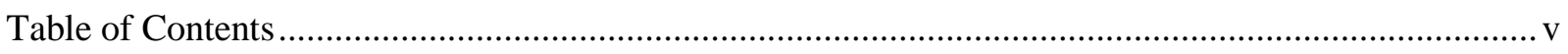

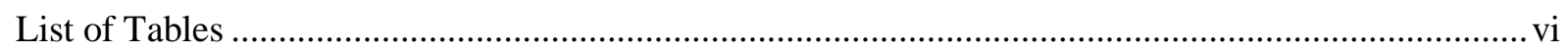

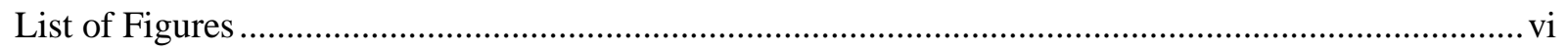

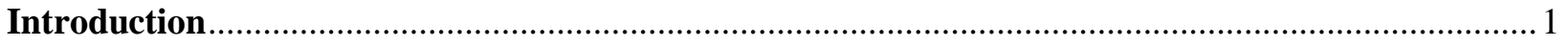

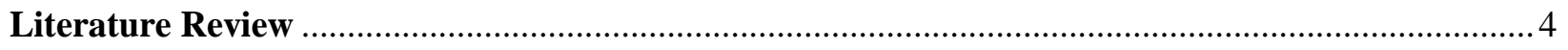

I. Government Policies and Associated Immigration Experiences of Newcomers in

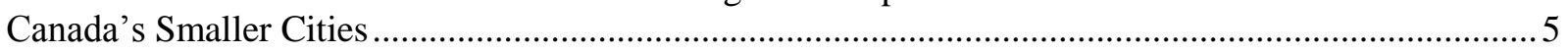

IA. Government Policies that Impact Immigrant Settlement into Smaller Cities ...............................5

IB. Reasons for Smaller Cities to Seek Higher Levels of Immigration ........................................... 8

IC. Impact of Pre-Migration Information on a Migrant's Choice of Settlement Destination ............. 10

ID. Growing Socio-Demographic Diversity as a Result of Greater Regionalization ........................ 11

II. Settlement Experiences of Newcomers in Canada's Smaller Cities ........................................... 12

IIA. Reasons why Newcomers, many of whom are Ethnic Minorities, Choose to Settle in Canada's

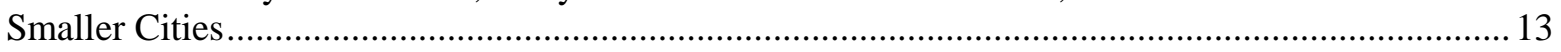

IIB. Newcomer Experiences in Smaller Cities ......................................................................... 18

IIC. Availability of Institutional Support in Smaller Cities ..........................................................20

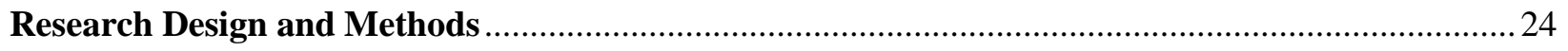

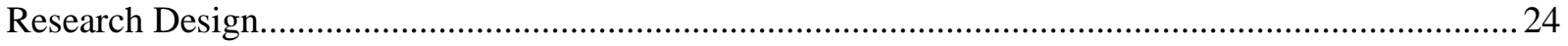

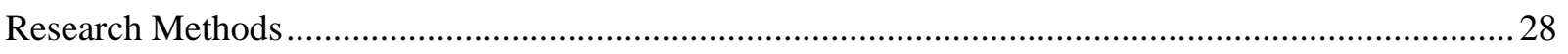

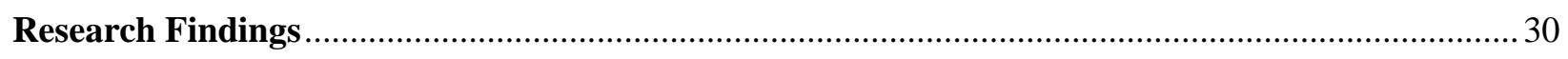

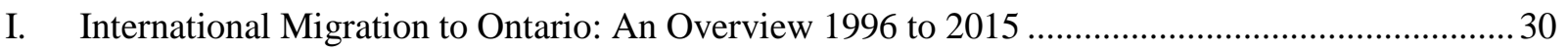

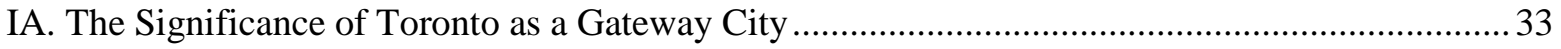

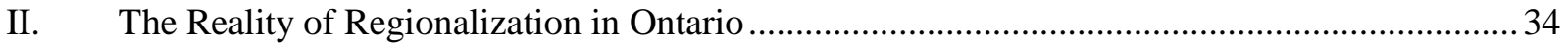

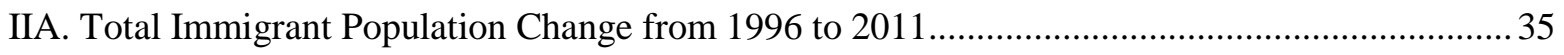

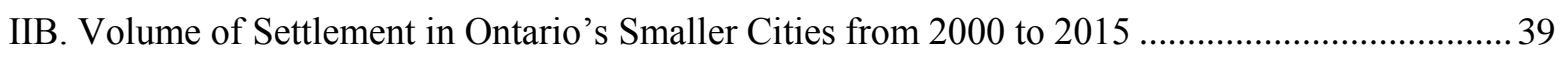

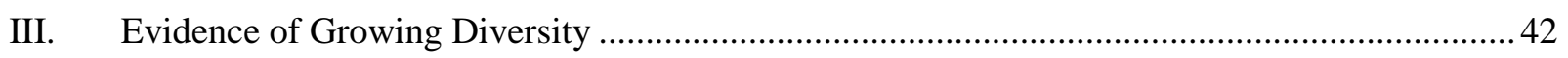

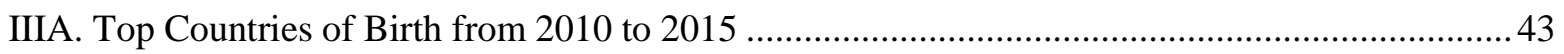

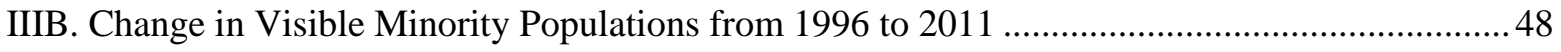

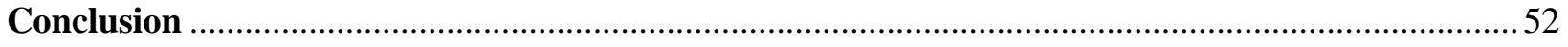

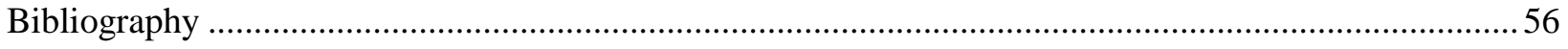




\section{List of Tables}

Table 1: Tiered System by Total Immigrant Population ...................................................... 26

Table 2: Percentage Immigrant Population in Tiers 4 and 5, 1996 and 2011 ......................... 35

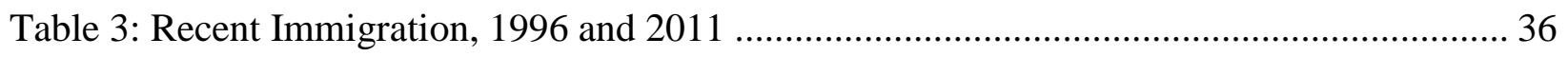

Table 4: Top Three Countries of Birth for Tier 4, 2001 to 2015 ............................................. 43

Table 5: Top Three Countries of Birth for Tier 5, 2001 to 2015 ............................................ 45

Table 6: Recent Immigrants by Country of Birth, 2011 ...................................................... 46

Table 7: Percent Share and Percent Change in Visible Minority Populations for Tiers 4 and 5 ,

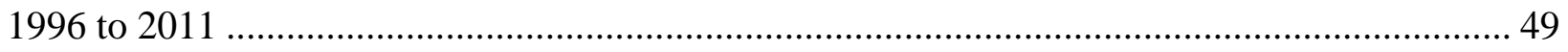

\section{List of Figures}

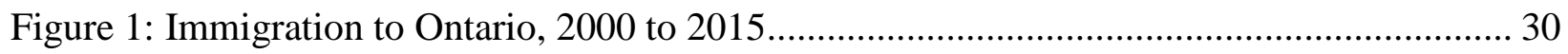

Figure 2: Visible Minority Population in Toronto and Ontario, 1996 to 2011 .......................... 32

Figure 3: Ontario Immigrants who Settle in Toronto, 2000 to 2015 ...................................... 33

Figure 4: Growth of Total Populations and Total Immigrant Populations in Tiers 4 and 5, 1996 to

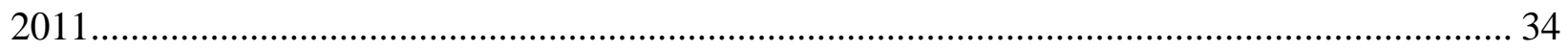

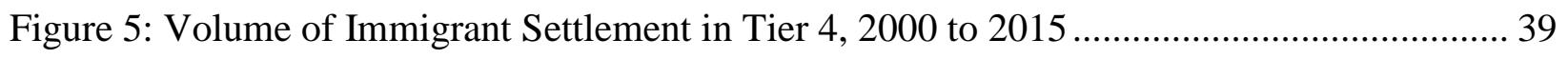

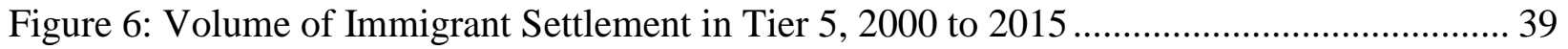




\section{Introduction: Section 1}

Over the last three decades, international migration to Canada has typically been characterized by the concentration of immigrants in three gateway cities, i.e., Toronto, Vancouver, and Montreal (Statistics Canada, 2013). Although in 2011 seventy percent of all Canadian immigrants lived in these three cities (Statistics Canada, 2013), policy makers have shown considerable interest in changing this overwhelming trend by attracting immigrants to other cities and smaller population centers. Toward that goal, in 2001 Citizenship and Immigration Canada (CIC) published a document, Towards a More Balanced Geographic Distribution of Immigrants to Canada, which highlighted that in order to fill labour shortages it is essential that Canada's smaller cities attract immigrants from overseas (CIC, 2001).

Settlement of immigrants outside of Canada's gateway cities or regionalization has been examined frequently (Bonikowska, Hou, \& Picot, 2015; Carter, Morrish, \& Amoyaw, 2008; Depner \& Teixeira, 2012; Derwing \& Krahn, 2008; Di Biase \& Bauder, 2005; Hyndman, Schuurman, \& Fiedler, 2006; Lusis \& Bauder, 2008; Walton-Roberts, 2011; Wulff, Carter, Vineberg, \& Ward, 2008). Since limiting the movement of people within the country is against Canada's democratic values (Carter et al., 2008), policy makers in these regions or provinces must provide significant incentives in order to attract immigrants. Changes to federal immigration policies, such as the adoption of the Provincial Nominee Program (PNP), allow Canadian provinces and territories to select suitable immigrants to meet their regional and local labour market needs (Carter et al., 2008; CIC, 2011). Provincial adoption of the PNP has led to the emergence of new geographical distributions of immigrants across Canada (Carter et al., 2008). For example, new immigrants have settled in the Western and Prairie Provinces. 
The settlement of new immigrants outside of Canada's gateway cities may impact all other regions of the country; however the available literature on this topic generally only addresses this trend relative to settlement into provinces that have not experienced significant immigration in the recent past (see Carter et al., 2008; Carter, Pandey, \& Townsend, 2010; Depner \& Teixeira, 2012; Hyndman et al., 2006). As immigration patterns have shifted westward, away from Ontario, it is not known how the social geography of international migration within Ontario has changed.

It is necessary to understand that Ontario is not a homogenous space despite the overrepresentation of Toronto in the literature. The volume and nature of immigration varies widely among the 15 Census Metropolitan Areas (CMAs) ${ }^{1}$ in the Province. Many of the smaller CMAs have considerable immigrant populations themselves. This paper is guided by a desire to understand how settlement has changed in Ontario's CMAs. To explore this I will be looking at the changing volume of immigrant settlement and social geography of eight of these CMAs from 1996 to 2015.

The paper will be structured as follows. In Section 2, the Literature Review, I will examine the existing Canadian literature on immigration and settlement in smaller cities. In particular, why do international immigrants choose smaller cities and what do the smaller cities do to attract them, what were their settlement experiences and what services do smaller cities provide to support their settlement.

\footnotetext{
${ }^{1}$ CMAs are defined as areas with total populations of 100,000 or more with a denser core population of at least 50,000 in the Census dictionary (Statistics Canada, 2012). Census agglomerations, which are also recorded in this category, were eliminated as they have smaller population sizes, only needing a population of 10,000 at their cores, with insufficient annual immigrant landings to demonstrate recent trends (Statistics Canada, 2012)
} 
In Section Three, Research Design and Methods, I develop a tiered categorization system of Ontario's CMAs using publicly available data. The data are drawn from the 1996, 2001, and 2016 Canadian censuses, the 2011 National Household Survey (NHS), and the permanent resident landing records (LIDS).

In Section 4, Research Findings, I explore and present descriptive statistics to better understand regionalization. I will compare two tiers of CMAs to reveal changes in the volume of immigrant settlement and social geography between 1996 and 2011 in Ontario.

Finally, in Section 5, Conclusion, I will summarize, discuss some of the major limitations of the study, and suggest areas of future research. 


\section{Literature Review: Section 2}

Research on international migration and settlement in Canada has a long tradition (Kelley \& Trebilcock, 2010). Under this broad area of study, much attention has been paid to documenting new and emerging source countries of newcomers to Canada and the challenges immigrants face and overcome in their settlement processes. Much of this research is focussed on immigrant experiences in Canada's gateway cities; Toronto, Montreal and Vancouver. Since 2001, when the federal government of Canada expressed an interest in moving "towards a more balanced geographic distribution of immigrants" (CIC, 2001), a growing body of literature has been emerging that seeks to unfold the immigration and settlement experiences of immigrants who have settled outside of these gateway cities ${ }^{2}$.

A review of the emergent literature on the immigration and settlement experiences of immigrants in Canada's smaller cities reveals that scholars have focussed on two broad, but interrelated themes: (I) Government policies and associated immigration experiences of newcomers in Canada's smaller cities; and (II) the settlement experiences of newcomers in these areas. There are four subtopics that have been explored under the first theme: (IA) Government policies that impact immigrant settlement into smaller cities; (IB) reasons for these cities to seek higher levels of immigration; (IC) impact of pre-departure information on the migrant's choice of settlement destination; and (ID) growing sociodemographic diversity in these cities. Under the second theme, three subtopics are discussed: (IIA) Reasons for newcomers, many of whom are ethnic minorities, to settle outside of

\footnotetext{
${ }^{2}$ For this paper, the focus will be on smaller cities; these exclude not only the major gateway cities, Toronto, Montreal and Vancouver, but also large cities that have developed a tradition of attracting large numbers of immigrants, such as Calgary, Winnipeg, and Ottawa.
} 
Canada's gateway cities; (IIB) newcomer experiences in smaller cities; and (IIC) the availability of institutional ${ }^{3}$ support for these immigrants.

\section{Government Policies and Associated Immigration Experiences of Newcomers in Canada's Smaller Cities}

\section{IA. Government Policies that Impact Immigrant Settlement into Smaller Cities}

In Canadian literature, three forms of government policy have been cited as affecting immigrants who settle in smaller cities. Regionalization policies are discussed as a way to increase the distribution of immigrants across the country (CIC, 2001). These discussions draw from international studies on regionalization and the policies of other immigrant receiving nations such as the United States, Australia, and New Zealand. Specific to Canada, the Provincial Nominee Program (PNP) is seen as a form of regionalization policy that has changed the national pattern of immigrant settlement, allocating some of the selection responsibility to individual provinces (CIC, 2011). Finally, immigrant selection policy affects the characteristics of the immigrants who land in smaller cities. Changes to the selection process of Canadian economic class immigrants places value on highly educated immigrants with high levels of official language knowledge.

\section{i. $\quad$ Regionalization Theory}

The increase in regional immigration policies around the globe is sometimes referred to as a "new paradigm" of international migration (Walton-Roberts, 2011; Wulff et al., 2008). Under this new paradigm, informed by the belief that increased immigration can stimulate economic and regional development in the periphery, governments encourage newcomers to settle outside of large, traditional gateway cities (Walton-Roberts, 2011; Wulff et

\footnotetext{
${ }^{3}$ For the purposes of this review, the term "institutions" represent all levels of government as well as community organisations, settlement services, educational institutions, and any stakeholder responsible for creating immigrant settlement policies or initiatives.
} 
al., 2008). This trend has been witnessed in Australia, New Zealand, the United States (US) and Canada (Wulff et al., 2008). The related policies are commonly referred to as regionalization policies as they promote increased regional distribution of immigrants and encourage regional actors to take a more direct role in developing initiatives to attract and retain immigrants (Walton-Roberts, 2007).

In Canada, as in Australia, New Zealand, and the US, increased immigration has been recognised as a way to stimulate the economies of smaller cities. Canadian policies are motivated by slow growing or declining populations due to aging and the outmigration of young people (Cappe, 2011; CIC, 2001; Wulff et al., 2008; Hyndman et al., 2006; Lusis \& Bauder, 2008). Intentions of regionalization in Canada have recently been reaffirmed by the current Minister for Immigration, Refugees and Citizenship Canada (IRCC, formerly CIC), John McCallum who stated that he "would like to spread the immigrants across the country relatively evenly" in a 2016 press conference as he stressed that he would like to avoid seeing increased concentration in Vancouver and Toronto (Johnson, 2016).

The emergent body of Canadian literature on the regionalisation of immigrants highlights a "westward" movement, where immigrants are attracted towards the Prairie Provinces (i.e. Alberta and Manitoba) (Carter et al., 2008; Carter et al., 2010; Derwing \& Krahn, 2008). Although these provinces were not seen as major immigrant receiving centres in the recent past, this region of Canada has seen significant historic immigrant settlement. Immigration historians have reflected on Canada's early history, when immigrants were actively recruited from abroad to settle and farm Canada's western regions (Kelley $\&$ Trebilcock, 2010). This was seen as necessary to increase the economic productivity of the region, increase the country's population, and most importantly, to reinforce the idea of 
Canadian sovereignty in reaction to its powerful neighbour, the United States (Kelley

$\&$ Trebilcock, 2010). Today the westward movement of settlement has been welcomed for similar reasons as it strengthens both the economies and the populations of these regions and to parallel history, the PNPs allow smaller provinces to reinforce their independent sovereignty to select newcomers that is similar to the way historic immigration was used as a form of nation building (Kelley \& Trebilcock, 2010).

ii. $\quad$ Provincial Nominee Programs

The Provincial Nominee Programs have given individual provinces and territories limited independent power to select immigrants who fit their labour market needs. The first of these programs was created in 1996 through an agreement between the federal government and the province of Manitoba (CIC, 2011). These agreements stem from section 95 of the Constitution Act of 1867 which outlines the shared role of immigration held by the federal and provincial governments (CIC, 2011). They have been developed through agreements between each province and territory (with the exception of Quebec and Nunavut) and the federal government such as the Canada-Ontario Immigration Agreement signed in 2005 (CIC, 2011). Through these agreements, provinces and territories are allotted a quota of immigrants which they can select to meet their specific needs; however, the federal government retains responsibility for the final stages of the process where immigrants are screened and receive permanent residence status (CIC, 2011).

The literature suggests that there is a connection between the PNP and regionalization in Canada (Bonikowska et al., 2015; Ferrer, Picot \& Riddell, 2014; Carter et al., 2008). For instance, likely contributing to the westward shift of immigrants, the province of Manitoba emerged early as a forerunner of the PNP with its program one of the first to become operational 
in 1999 (CIC, 2011). This contributed to Manitoba's rising share of immigrants to Canada from $2.0 \%$ in 2000 to $5.6 \%$ in 2010 (Bonikowska et al. 2015).

\section{iii. $\quad$ Immigrant Selection Policy}

Those immigrants selected through the PNP are economic immigrants, chosen for their potential to contribute to the specific economic needs of each province. All economic immigrants, whether admitted through federal or provincial programs are carefully selected for their economic potential. Immigrant selection policy has been increasingly focused on human capital factors in recent decades (Kelley \& Trebilcock, 2011). This means that greater value has been placed on factors such as education and knowledge of the official languages in potential immigrants. This preference was solidified in the 1997 report, Not Just Numbers: a Canadian framework for future immigration (Trempe, 1997). This report highlighted the importance of selecting immigrants with high human capital to increase their potential to contribute to the Canadian economy (Trempe, 1997). This policy has continued to impact economic immigrants as both the federal and provincial selection policies reflect the desire for high human capital (Ferrer et al., 2014). In spite of these selection policies, many new immigrants continue to struggle to establish themselves economically in Canada. Many studies report a mismatch between the potential of newcomers and their underemployment in Canada (Sethi, 2015; WilsonForsberg, 2015).

\section{IB. Reasons for Smaller Cities to Seek Higher Levels of Immigration}

It was mentioned earlier that increased immigration has been recognised as a way to stimulate the economies of smaller Canadian cities and to help slow or stop population decline due to aging and the outmigration of young people (Cappe, 2011; CIC, 2001; Wulff et al., 2008; Hyndman et al., 2006; Lusis \& Bauder, 2008). This is also seen to be beneficial in developing 
regional economies, and overall increasing Canada's diversity outside of major urban centres (Krahn, Derwing \& Abu-Laban, 2005). These benefits have been recognised by many smaller cities which have begun to develop initiatives in an attempt to increase their attractiveness to potential immigrants. An example of this is the Community Support stream of the Manitoba PNP (Carter et al., 2008). This stream attracted newcomers to fill acute labour market shortages in specific small cities by supporting their applications for nomination (Carter et al., 2008). It is through initiatives like this that the Manitoba PNP has been so successful and is considered a model to other provinces (Carter et al., 2008; Carter et al., 2010). Without deeper involvement in this process other smaller Canadian immigrant reception areas will not reap the benefits of increased immigration.

Greater geographic distribution of newcomers would also take some of the pressure off of Canada's gateway cities (Krahn et al., 2005). There is some concern among scholars that the concentration of immigrants in so few major cities may increase social tensions through rapid change in the demographics and racial diversity of these areas (Hyndman et al., 2006; Wulff et al., 2008). While the desire for greater distribution is not a direct response to the growing populations of immigrants in traditional gateway cities, there is some concern that this concentration may be detrimental to the settlement experiences of these newcomers as they often face higher unemployment and poverty rates, lack affordable housing and overburdened settlement services (Cappe, 2011). As a result of this, scholars have suggested that regional actors should take interest in regionalization as it would decrease competition in Canada's gateway cities (Krahn et al., 2005). There is also some concern that increased immigrant concentration in major urban centres will raise housing prices (Ley \& Tutchener, 2001). These 
factors have promoted a desire for increased regional distribution of immigrants across Canada.

\section{IC. Impact of Pre-Migration Information on a Migrant's Choice of Settlement Destination}

Initial settlement destinations are decided in the pre-migration stage (Di Biase \& Bauder, 2005). This is when potential immigrants learn about Canada and formulate their perceptions of what their settlement experience will be like. Much of the essential knowledge of the immigration process is acquired in this stage of migration and yet it is a stage that has received very little dedicated attention. Pre-migration information is frequently acquired through informal methods, such as from conversations with established friends and family members, and from information found through the internet (Di Biase \& Bauder, 2005; Derwing \& Krahn, 2008; Lusis \& Bauder, 2008). Lusis and Bauder (2008) have shown this technological link to be important past the point of settlement in their research on Filipino immigrants in Guelph, Kitchener-Waterloo and Niagara Falls, as the internet is used as a resource to maintain transnational ties to the source country as well as provide valuable information. They have also shown that it is more often the internet and social circles in the immediate vicinity that immigrants in small communities turn for support rather than interacting with larger co-ethnic communities that may be found in larger urban centres (Lusis \& Bauder, 2008; Da, 2010). These informal information sources are especially important for immigrants deciding to settle in smaller cities, as formal information pathways, such as official pre-migration services and federal migration webpages offer scarce information on living outside of major gateway cities (Lusis \& Bauder, 2008). 
Analyzing this topic, Canadian scholars have pointed out that official pre-migration information must clearly convey the challenges and barriers many immigrants face in entering the labour market once in Canada, with more accurate information potential immigrants could better prepare for the specific conditions of the regions where they intend to settle (Lusis \& Bauder, 2008; Derwing \& Krahn, 2008). It is essential for newcomers to fully understand the economic conditions that they will be facing upon their arrival to Canada so they can do as much as possible to prepare in the pre-migration period (Lusis \& Bauder, 2008). There are few ideas on how to effectively convey this information. Immigrant communities, their transnational networks, and the internet are the most effective ways that potential immigrants learn about migrating to cities outside of major gateways. It seems as though official routes often overlook these smaller communities and are thus ineffective on promoting regionalization through pre-migration networks (Lusis \& Bauder, 2008). Further research is necessary in order to determine best practices for encouraging a more geographically diverse settlement of immigrants across Canada through effective pre-migration information (Lusis \& Bauder, 2008).

\section{ID. Growing Socio-Demographic Diversity as a Result of Greater Regionalization}

As smaller cities develop plans to facilitate the settlement of growing numbers of immigrants due to changing settlement patterns they will often experience growing diversity (Bonikowska et al., 2015; Olson \& Kobayashi, 1993). Recent immigrants are more predominantly originating from non-traditional source countries ${ }^{4}$, which has an effect on the demographics of smaller, more homogeneous communities (Bonikowska et al., 2015; CIC, 2001). This diversity has many social and economic benefits. However, this pattern has also

\footnotetext{
${ }^{4}$ Traditional source countries in Western and Northern Europe, such as the U.K., Italy, the Netherlands, and Germany, accounted for a significant proportion of historic immigration to Canada prior to the 1970s (Statistics Canada, 2013)
} 
created challenges for communities as they attempt to create culturally appropriate plans and provide effective support services (Federation of Canadian Municipalities, 2008).

Scholars have shown a connection between increased diversity and increased economic development which has contributed to the desire of many smaller communities to attract more immigrants (Walton-Roberts, 2011). As immigration continues outside of traditional gateway cities, diversity in the rest of Canada will grow. There is some concern that immigrants who settle in the largest cities tend to see lower employment earnings and instances of employment than those who live in smaller cities (Hyndman et al., 2006; Di Biase \& Bauder, 2005; Frideres, 2006). The concentration of co-ethnic immigrant populations may be detrimental for their ability to enter the broader labour market and develop their official language skills; the impacts of these settlement patterns are debated in the literature (Depner \& Teixeira, 2012; Wulff et al., 2008). Racialized immigrants in particular struggle to be recognised and may also have difficulty achieving institutional visibility (Winders, 2012). Institutional visibility refers to the way a group is seen by institutions and the government within a community; this is particularly pertinent for immigrants who are often discussed as a political issue rather than participating members of society (Winders, 2012).

\section{Settlement Experiences of Newcomers in Canada's Smaller Cities}

In this section, the extant literature which addresses the settlement experiences of newcomers in Canada's smaller cities is reviewed. Under this theme there seems to be three interrelated strands of inquiry: first, why do newcomers choose to settle in Canada's smaller cities; second, what kind of experiences (negative and positive) do they encounter during their process of settlement in these geographical areas; and third, what kinds of institutional support 
do they receive during their settlement process. Better understanding of the answers to these three questions will be developed in the following three corresponding sections.

\section{IIA. Reasons why Newcomers Choose to Settle in Canada's Smaller Cities}

One of the most significant ideas that arises in regionalisation literature is how greater diversification of immigrant settlement will not only be beneficial to the smaller regions in terms of economic and population growth, but will also be beneficial to those immigrants who choose to settle outside of the major gateway cities (Depner \& Teixeira, 2012).

Scholars have pointed out that newcomers to Canada make the decision on where to settle based on a variety of factors including friends and family, employment and educational opportunities, lifestyle, climate, and appropriate housing (Hyndman et al., 2006; Depner \& Teixeira, 2012; Walton-Roberts, 2011). Immigrants may choose to settle in Canada's smaller cities due to a number of factors that can be both external and internal. Among the external factors (i.e., factors that are outside of their control, and newcomers are "responding" to these stimuli), are perceived economic opportunities, the presence of institutions of higher education, and housing prices in the intended destinations. The internal factors that reflect the newcomers' own preferences are proximity to co-ethnic communities in large gateway cities and strong ties to the established community through the presence of family or friends.

\section{$\underline{\text { External Factors }}$}

I. $\quad$ Perceived Economic Opportunities

Many Canadian scholars have argued that immigrants make their settlement destination choices based on economic opportunities (Derwing \& Krahn, 2008; Hyndman et al., 2006; Sethi, 2015; Wilson-Forsberg, 2015). The choices of different types of immigrants were highlighted by Ghosh (2014), who found that high- and low-skilled immigrants have different motivations. It 
was found that higher-skilled immigrants were more likely to migrate for economic reasons that related to their economic networks, whereas lower-skilled immigrants were more likely to rely on their strong ties to friends and family when making these decisions (Ghosh, 2014). With economic immigrants entering the country through increasingly high human capital programs, it is likely that the immigrants in this stream will be drawn to destinations with economic opportunities (Bonikowska et al., 2015; Derwing \& Krahn, 2008). Bonikowska et al. (2015) stated that "a favorable economic climate was the main factor in the increase in a destination's share of new immigrants" (p. 18). Migration influenced by these factors could be seen in the movement of high numbers of immigrants to Alberta over the 2000s, due to perceived opportunities in the regional labour market as the result of high oil and gas prices (Derwing \& Krahn, 2008). This is essential for smaller cities to understand as productive regional economies are integral to attract increased immigrant settlement to new regions (Hyndman et al., 2008).

\section{ii. Presence of Institutions of Higher Education}

Walton-Roberts (2011) found that universities and colleges can be central to an immigrant's choice of settlement destination and integration in smaller cities. This is particularly relevant for Ontario as the majority of immigrants who enter through the Ontario Immigrant Nominee Program (OINP) do so through international student streams (Office of the Auditor General of Ontario, 2014). With this being the case, it becomes more important to consider educational institutions as attractors of new immigrants and pathways through which they can become integrated into Canadian social and economic society (Walton-Roberts, 2011). As the institutions themselves realize this and further develop their position as pathways to permanent 
residence, they have the opportunity to provide many essential supports to international students (Walton-Roberts, 2011).

Institutions of higher education can be seen as streams through which smaller communities may begin to change the composition of their populations by attracting immigrants belonging to visible minority groups ${ }^{5}$. These institutions can act as safe spaces to newcomers who see universities and colleges as places where they encounter lower levels of discrimination (Walton-Roberts, 2011). The presence of a large educational institution can promote the idea of the welcoming community in smaller cities due to the compact size of campuses which increase access to amenities (Walton-Roberts, 2011). In addition to this, the development of large numbers of well-educated individuals that arise from institutions of higher education may be a significant attractor for employers (Walton-Robert, 2011). This may further contribute to the retention of international students as immigrants in some smaller cities.

\section{iii. Housing Prices}

New immigrants to Canada must consider a number of variables throughout the settlement process. As part of this process they must find housing in whichever region they decide to settle. Hyndman et al. (2006) found, that in British Columbia, there was a positive correlation between the desirability of a settlement location and housing prices. Di Biase and Bauder (2005) found a similar correlation in Ontario, where more immigrants concentrated in areas with higher housing prices (Di Biase \& Bauder, 2005; Hyndman et al., 2006).

The housing supply in smaller communities does not always match the needs of newcomers and it is essential that appropriate and affordable housing be available in these communities (Derwing \& Krahn, 2008). Teixeira (2009) investigated housing issues in regards

\footnotetext{
${ }^{5}$ The term visible minority is defined under the Employment Equity Act as "persons, other than Aboriginal persons, who are non-Caucasian in race or non-white in colour" (Statistics Canada, 2013).
} 
to the smaller city of Kelowna in British Columbia and found that immigrants sometimes struggle to find adequate housing that meets their basic needs. As a result of this, he found that newcomers often rely on close friends or family in the early stages of their settlement (Teixeira, 2009); this could indicate that while housing is an integral aspect of the settlement process, it may not be a significant factor in the settlement location decision.

\section{Internal Factors:}

\section{i. $\quad$ Proximity to Co-Ethnic Communities in Large Gateway Cities}

Some scholars have found that among immigrants in smaller communities there exists a perception that settling in the larger ethnic communities in gateway cities may be detrimental to their integration and ability to access official labour markets (Lusis \& Bauder, 2008). It was felt by some newcomers that this would isolate them from the broader Canadian society (Lusis $\&$ Bauder, 2008). This is seen to be less of an issue outside of the gateway cities as the small size of ethnic communities in these areas encourages significant interaction with non-immigrant community members and across different ethnic groups (Lusis \& Bauder, 2008; Carter et al., 2008). However, an absence of friends and family members can also make it difficult to develop immigrant communities which can offer significant support to newcomers (Krahn et al., 2005). Strong incentives must be in place to successfully attract and retain immigrants in smaller communities (Hyndman et al., 2006). It has been argued that if a critical capacity of co-ethnic immigrants settles in smaller cities then they may be able to attract and retain an increased number of future immigrants (Krahn et al., 2005).

Proximity of a settlement location to a major immigrant destination, such as Toronto, can affect the way it is perceived by newcomers. This proximity can be seen by some as improving access to settlement services and access to the labour market (Hyndman et al., 
2006). Lusis and Bauder (2008) discovered in their research on Filipino immigrants in smaller cities in Ontario that some newcomers purposely avoid developing a reliance on the settlement services or co-ethnic communities in Toronto despite their relative proximity and the efficient transportation linkages in southern Ontario (Sweet, Bullivant, \& Kangaroglou, 2016). However, improvements to transportation systems linking smaller cities with larger urban centres has been connected to the development of 'dispersed cities' as the economies of these smaller regions become linked with that of the larger urban centre (Everitt \& Gill, 1993, p. 254; Sweet et al., 2016).

\section{ii. Presence of Strong Ties of Friends or Family in the Smaller Cities}

Wulff et al. (2008) have pointed out that "Jobs may not be enough" (p.23) to attract immigrants to these smaller cities. In that sense, even though economic factors are more often thought of as the most significant factor for a newcomer's settlement location decisions, connections with established immigrants already living in these smaller cities can be a significant determining factor for newcomers to choose smaller cities. Some scholars have also argued that employment opportunities play a larger role in the retention of immigrants than in than in their attraction (Di Biase \& Bauder, 2005). Social factors, such as the presence of friends and family members, may play a more decisive role in the settlement decision making process than economic factors (Di Biase \& Bauder, 2005). This is likely due to chain migration, a process that “...implies that there are primary and secondary migrants who are active and passive, leaders and followers, pioneers and colonists. The pioneer migrants make the first move from the origin area and are then followed by members of the secondary group." (Croes \& Hooimeijer, 2010, p.123). 
Many scholars have shown that close friends and family are the most common source of support on which newcomers rely (Da, 2010; Teixeira 2009; Lusis \& Bauder, 2008). These social networks are integral in the initial stages of settlement as they contribute to housing choices and provide valuable information on employment opportunities (Teixeira, 2009; Wilson-Forsberg, 2015). In this way, the networks that immigrants turn to for support are similar in gateway cities and smaller communities. It has been found that personal networks are used more frequently than official support services, such as settlement organisations, in this initial settlement period (Lusis \& Bauder, 2008; Teixeira, 2009).

In addition to this, the literature reveals that large co-ethnic communities may not be essential for attracting newcomers; rather it is direct personal contacts, such as, family, friends, and employers who provide the most significant incentive to settle in a particular location (Hou, 2007). However, more research is needed to determine the benefits and support received from personal contacts when there is no pre-existing large co-ethnic community.

\section{IIB. Newcomer Experiences in Smaller Cities}

Discrimination can be a major barrier to the successful integration of newcomers into any community, but especially in smaller cities where the populations are less diverse (Baker et al., 2016). Discrimination and racism are often seen, both by the Canadian-born population and immigrants themselves, as being a much larger issue on the federal level and in large gateway cities (Baker et al., 2016; Lusis \& Bauder, 2008). Olson and Kobayashi (1993) recognised that "immigrants experience pressures associated with concentration" (P.142) when they settle in Canada's gateway cities. They saw this concentration to increase incidences of racism and linked it to the process of negotiating space for oneself in an emerging mosaic (Olson \& Kobayashi). Discrimination has been shown to impact many levels of the settlement process, in 
the initial stages there are often difficulties in finding housing and rental opportunities due to discrimination towards immigrants; this is especially prevalent towards immigrants who are racialized or lack strong communication skills in either of Canada's official languages (Teixeira, 2009).

The demographic transformations of smaller cities are often not anticipated by the communities due to the assumption that immigrants are perceived primarily for their economic potential, rather than their community membership (Lichter, 2012). As a result of this, diversity is often forced to fit into the parameters of the established community and new members can suffer from being encouraged to integrate in a one-sided process (Lichter, 2012; Voyer, 2015). These challenges are faced by all immigrants, but especially by those who are racialized and this must be addressed through deeper community and municipal involvement in the integration process (Voyer, 2015). Walton-Roberts (2007) expressed support for this idea when she stated that "sustainable immigrant settlement is also more likely to succeed if it is community driven and entails a long-term and broad-based model of incorporating immigrants into communities as community builders and stakeholders" (p. 14). Communities must be “welcoming communities"."(Wulff et al. 2008, p. 123). The failure to do so can lead to challenges with discrimination as the populations of these smaller cities may feel uncomfortable with growing diversity (Ray \& Preston, 2013).

Lund and Hira-Friesen (2013) have shown that there is a generally higher level of trust between people who live in smaller communities than between those living in large urban centres. More significantly, they found that racialized immigrants who live in smaller communities are considerably less concerned about hate crimes than those who live in urban areas (Lund \& Hira-Friesen, 2013). Immigrants often select smaller cities because they are seen 
as being more safe and family friendly (Lusis \& Bauder, 2008). Studies have shown that many immigrants see smaller communities in Ontario as having less violence and populations that are more likely to accept newcomers; this this is highlighted by perceptions that some immigrants have about the relative racial tension and increased violence in Toronto (Lusis \& Bauder, 2008).

In general, a lack of acknowledgement of racism and discrimination by Canadian-born members of smaller communities has been found, which calls for stronger education on these issues to build awareness (Ray \& Preston, 2013). It is necessary to reinforce the idea of immigrants as members of the community and to implement a two-way method of integration where the entirety of the burden to become part of Canadian society is not placed on the newcomer (Lichter, 2012). This implies that there is some possibility, that with more municipal involvement and the distribution of information, that instances of racism and discrimination can be addressed to improve the settlement experience of immigrants in small cities.

\section{IIC. Availability of Institutional Support in Smaller Cities}

Literature on the settlement experiences of newcomers in Canadian cities points to the increasing role of municipal level institutions in this process. Scholars have documented settlement services outside of traditional gateway cities (see Chadwick \& Collins, 2015; Depner \& Teixeira, 2012; Sethi, 2013; Wang \& Trulove, 2003). Appropriate and generous support for newcomers must be underscored as "the conditions under which migrants are received help define the sense of ethnic community that emerges, since each wave of arrivals is a new encounter, provokes a need for new forms of communication, and raises questions about existing privileges" (Olson \& Kobayashi, 1993, p.141). This section will present what has been found by scholars to support the availability of various aspects of settlement services in smaller cities. 


\section{i. $\quad$ Availability of Settlement Services}

Settlement services can increase a community's ability to adequately welcome newcomers (Hyndman et al., 2006). However, funding for settlement services is not equal across all Canadian communities which can create some disparities (Wang \& Trulove, 2003). Without adequate newcomer support smaller cities will face problems with retention. They will not see the benefits of increased immigration if they are unable to create supportive and welcoming communities (Depner \& Teixeira, 2012; Lund \& Hira-Frisen, 2013). Canadian studies on settlement services in smaller cities have addressed the availability of many different types of services, such as, language training (Wang \& Trulove, 2003), employment and labour market training (Sethi, 2015; Wilson-Forsberg, 2015; Depner \& Teixeira, 2012; Lo \& Teixeira, 2015), housing assistance (Teixeira, 2009), and mental health support (Chadwick \& Collins, 2015; Sethi, 2013).

Chadwick and Collins (2015) found that there was greater social support in smaller urban centres, despite this, those immigrants living in smaller urban centres also reported lower levels of self-perceived mental health (Chadwick \& Collins, 2015). There is a correlation between immigrant mental health and the availability of social support during the settlement period (Chadwick \& Collins, 2015). Immigrant serving organizations in smaller cities were found to more frequently provide tangible support services, such as accompanying their clients to appointments, than those in larger urban centres which fosters the development of closer ties between the organizations and their clientele (Chadwick \& Collins, 2015). Communication barriers present a greater challenge in smaller communities as there is less likelihood of clients being served by service providers of the same ethnicity or language background (Chadwick \& Collins, 2015). This is made more challenging by the diversity of source countries from 
which newcomers originate; in addition to their small numbers this has been a primary reason why there are few ethno-centric service providers in smaller communities (Depner \& Teixeira, 2012).

\section{ii. Impacts of Settlement Services on the Settlement Experience}

Scholars have pointed out that smaller cities often lack significant history as immigrant destinations and the small numbers of newcomers in these communities make it difficult to adequately and appropriately serve their needs through dedicated service providers (Wang $\&$ Trulove, 2003). Newcomers in smaller cities may also lack awareness of the variety of services available to them (Wang \& Trulove, 2003). Many newcomers see settlement services as primarily providing language training and therefore do not seek them out for help with their preliminary settlement needs (Wang \& Trulove, 2003). By the time newcomers access services to improve their official language and communication skills, they have often already undergone many of the initial stages of settlement without guidance from dedicated immigrant serving organisations, such as having found employment and housing due to lack of awareness or limited availability of these programs (Depner \& Teixeira, 2012; Wang \& Trulove, 2003).

\section{Emergent research Questions}

It is clear that there are some significant gaps in the literature on settlement outside of gateway cities in Canada. From these gaps arise several research questions that will help to understand the realities of regionalization. While studies which illuminate the process of regionalization in western provinces exist, there is a dearth of literature on the impact of this trend on the most populous province of Ontario. Little is known about the actual changes of settlement patterns over time in Ontario. While studies such as those by Sethi (2015) and Lusis and Bauder (2008), discuss the patterns of increased settlement outside of Ontario's 
gateway city, they are among the few and both focus on the experiences of specific communities. Therefore, in the next section I will outline how I will be assessing the volume of immigrant settlement across the province. Additionally, though some scholars have focused on specific visible minority groups in Ontario, such as Lusis and Bauder's 2008 study of Filipino immigrants or Da's 2010 study of Chinese immigrants of London, little is known about changing diversity across Ontario's smaller cities, and how these patterns have changed in recent decades. This research is necessary to highlight additional communities in need of further scholarly attention.

This exploratory research will provide a descriptive overview of regionalization in Ontario, with further questions regarding the capacity of municipal stakeholders to welcome newcomers and facilitate their settlement stemming from the findings of this paper. This research question was originally intended to be the focus of this project, but a review of the extant literature revealed significant gaps that had to filled before an assessment of municipal initiatives could be attempted. With the exception of Lusis and Bauder's (2008) analysis of Filipino settlement in the province, the reasons behind immigrant settlement and the changing volume of annual landings in Ontario has not been investigated. Entire communities that have seen very little scholarly attention fall through these gaps in the literature. This paper further highlights the need to see immigration and settlement as a transnational process. The author urges future research in this area to consider the importance of the pre-migration period in the decision making process for settlement locations and information gathering. 


\section{Research Design and Methods: Section 3}

The objective of this research is to assess immigrant settlement in Ontario between 1996 and 2015. The following interrelated research questions will be discussed through this paper (i) what has been the volume of international migration to the smaller cities in Ontario, outside of Toronto, between 1996 and 2015; and (ii) how has the social geography of these cities changed over this period of time. In order to investigate these research questions, five secondary data sources were used: the Canadian census of 1996, 2001, and 2006 as well as the National Household Survey (NHS) ${ }^{6}$ of 2011 and Immigrant Landing Records from 2000 to 2015. Primary data sources such as interviews with immigrants and stakeholders were not deemed as an appropriate research method due to the exploratory nature of the project and limitations of time. In the next section of this chapter, I will describe the research design of this project followed by the research methods that were used to answer the research questions mentioned above.

\section{Research Design}

This project focuses on the province of Ontario primarily because Ontario has been the most popular immigrant destination in Canada. Toronto, Ontario's capital city has been a main gateway city since the post-war period, with close to one third of all Canadian immigrants settling in this city by the 1970's (Troper, 2003). As has been mentioned in Section 2, since the mid-1990s, a large volume of social science research in Canada has focused on immigration and settlement. While most of this research has focused on the Canadian gateway cities of Toronto, Montreal, and Vancouver (TMV), smaller cities in Canada outside of the TMV have received

\footnotetext{
${ }^{6}$ The 2011 National Household Survey was used in place of the 2011 Canadian census as it had replaced the longform census in 2011. This survey was voluntary; as a result, it had a response rate of 68.6\%. However, Statistics Canada took several steps to ensure that the results were representational. See http://www23.statcan.gc.ca/imdb/p2SV.pl?Function=getSurvey\&SDDS=5178 for more information.
} 
much less attention. This has been the major trend, despite the fact that the federal government is interested in creating a more geographically balanced distribution of immigrants across the country (CIC, 2001). This policy would see increased settlement in provinces and regions that had not previously experienced high levels of settlement. Therefore, it is imperative to understand how the policy of regionalization has affected the migration and settlements of immigrants in the smaller cities of Ontario. In initially considering the literature on regionalization, I noted that even though this policy had been encouraged federally, it has mostly been discussed with regards to the Prairie Provinces (see Derwing \& Krahn, 2008; Carter et al., 2008). Another related reason for choosing Ontario is that the total share of Canadian immigrants to this province has decreased in recent decades, with the percent of immigrants settling in Ontario falling to 38\% of the total in 2015 from 60\% in 2001 (Cappe, 2011; LIDS, 2016). Therefore, I wanted to understand how these changes may have affected the smaller cities within the province.

It has been mentioned above that although some research has been conducted on immigrant settlement into smaller cities in Ontario, for example, Guelph, Kingston, Kitchener-Waterloo, and Niagara (see Chadwick \& Collins, 2015; Di Biase \& Bauder, 2005; Lusis \& Bauder, 2008; Walton-Roberts, 2007; Walton Roberts, 2011), to my knowledge none of these studies have assessed the overall migration trends across the province. This literature has left a gap in the comprehensive understanding of settlement across the province. While the extant studies provide an understanding of settlement at the community level in smaller cities or groups of cities, they have not contributed to research on different levels of settlement across the province. This makes assessment of regionalization policy or provincial settlement directives challenging. In view of these gaps, it seems that a consistent terminology is 
needed in order to understand immigrant settlement in cities across the province. To address this, I have developed a tiered categorization system to better assess how immigrant settlement impacts different types of cities with more or less historic settlement. In the next section I will describe the process through which this categorization scheme was developed for this project which led to slotting all fifteen of Ontario's Census Metropolitan Areas (CMAs) into six tiers.

Table 1: Tiered System by Total Immigrant Population

\begin{tabular}{|c|c|c|c|c|}
\hline \multirow[b]{2}{*}{ CMAs } & \multicolumn{4}{|c|}{ Year } \\
\hline & 1996 & 2001 & 2006 & 2011 \\
\hline \multicolumn{5}{|c|}{ Tier $1: 500,000+$ Immigrants in 2011} \\
\hline Toronto & $1,772,905$ & $2,032,960$ & $2,320,165$ & $2,537,410$ \\
\hline \multicolumn{5}{|c|}{ Tier 2 : 200,000 - 500,00 Immigrants in 2011} \\
\hline Ottawa-Gatineau & 161,885 & 185,010 & 202,735 & 235,335 \\
\hline \multicolumn{5}{|c|}{ Tier 3 : 100,000 - 200,000 Immigrants in 2011} \\
\hline Hamilton & 145,660 & 154,660 & 166,630 & 166,755 \\
\hline Kitchener-Cambridge-Waterloo & 82,765 & 90,570 & 103,060 & 108,720 \\
\hline \multicolumn{5}{|c|}{ Tier 4 : 50,000 - 100,000 Immigrants in 2011} \\
\hline London & 75,975 & 80,410 & 87,420 & 87,655 \\
\hline Windsor & 56,990 & 67,875 & 74,770 & 70,285 \\
\hline St. Catharines-Niagara & 67,285 & 66,050 & 70,320 & 64,390 \\
\hline Oshawa & 44,105 & 46,150 & 53,920 & 56,175 \\
\hline \multicolumn{5}{|c|}{ Tier 5 : 15,000 - 50,000 Immigrants in 2011} \\
\hline Guelph & 21,200 & 22,865 & 25,765 & 27,515 \\
\hline Barrie & 13,475 & 17,065 & 22,515 & 22,350 \\
\hline Kingston & 17,840 & 17,675 & 18,505 & 18,090 \\
\hline Brantford & 14,375 & 12,125 & 15,935 & 15,080 \\
\hline \multicolumn{5}{|c|}{ Tier 6 : Less than 15,000 Immigrants in 2011} \\
\hline Thunder Bay & 15,275 & 13,315 & 12,600 & 10,895 \\
\hline Greater Sudbury & 12,035 & 10,775 & 10,450 & 9,775 \\
\hline Peterborough & 9,140 & 8,985 & 10,795 & 9,495 \\
\hline
\end{tabular}

Source: Statistics Canada, 1996, 2001, 2006, and 2011 
The tier system was developed using the variable of total immigrant population from the $2011 \mathrm{NHS}^{7}$. This was the variable that resulted in the most consistency; however, other variables such as percent immigrant population, proximity to Toronto, and CMA size were tested in the initial stages of the project. The initial shortlist of areas chosen for the tiered system was the complete list of CMAs in Ontario as shown in the 2011 NHS. This tiered system is displayed in Table 1. The individual tiers were determined based on groupings of CMAs with similar total immigrant populations in 2011. For this paper, the focus will be on Tiers 4 and 5. Tier 6 was discounted as the immigrant populations in these CMAs are too small to be representational. Furthermore, these CMAs have seen stagnant or decreasing immigrant populations in the past 15 years. Tiers 1 through 3 will be discussed briefly, however, the CMAs within these tiers have been the subject of the most scholarly attention and their immigrant populations are better understood than those in Tiers 4 and 5. Tier 4 consists of emerging immigrant destinations; these have seen consistent historical immigrant settlement. Tier 5 is made up of much newer immigrant destinations without significant history of welcoming those immigrants originating from non-traditional source countries. In this tier, Guelph has arisen as a particularly significant CMA. With a high proportion of immigrants, Guelph will likely develop into an emerging immigrant destination and may belong in Tier 4 in the future.

With this in mind, I chose to compare Tiers 4 and 5 because their size and position as small and emerging cities would provide the best cases to assess the development of more geographically diverse settlement patterns in Ontario. These two tiers will be compared against each other to reveal how cities with different immigrant populations are being impacted by

\footnotetext{
${ }^{7}$ In the 2011 National Household Survey, an immigrant refers to "a person who is or has ever been a landed immigrant/permanent resident. This person has been granted the right to live in Canada permanently by immigration authorities. Some immigrants have resided in Canada for a number of years, while others have arrived recently. Some immigrants are Canadian citizens, while others are not." (Statistics Canada, 2012)
} 
settlement and the changing socio-economic characteristics of immigrants and the CMAs within each tier will be compared to highlight any outliers. Comparisons are necessary to establish general trends that have not yet been studied in regards to the province of Ontario with the use of recent data. I believe it is important to state that the scale of this project is a major constraint, the time available and length of the paper restricted my ability to engage as deeply as desired with this topic. I aim to address some of the significant gaps in the literature and create a framework to direct future scholarly research. The secondary data sources were sufficient to provide the preliminary descriptive findings that were necessary for this project.

\section{Research Methods}

As mentioned above, two secondary data sources were used to investigate research question one: what has been the volume of international migration outside of Toronto between 1996 and 2015. These were the community profiles of each CMA from the Canadian census (1996, 2001, and 2006), the 2011 National Household Survey (NHS), and the Permanent Resident Landings Records from 2000 to 2015 at the CMA level. Research question two: how has the social geography of Ontario's smaller cities changed between 1996 and 2015, relies on the same two data sources. From the census, this section uses the variable of visible minority population at the CMA level. Additionally, country of birth data from the landings records serves as a proxy variable to identify the impact of traditional source counties on smaller cities.

Census data from 1996, 2001, 2006, and the 2011 NHS are publically available data sources which provide highly useful data. These sources were used to determine the changes in the total populations, immigrant populations, recent immigrant populations, recent immigrant source countries, and visible minority populations over time for each CMA. While these are extremely useful for assessing overarching statistics, they are less useful for isolating individual 
populations. Using publically available data alone, this research would have been limited to determining the volume of immigrant settlement in smaller cities in Ontario. To expand the scope of the project and understand more significant characteristics of these populations, it was necessary to supplement the publically available data with landings data.

Landings data are collected for all immigrants to Canada at their point of landing by Immigration, Refugees and Citizenship Canada (IRCC). For this study, records of Permanent Residents were used for the period of 2000 to 2015 . These data were available at the CMA level for all regions within Ontario. These data allowed for a more in depth analysis of the changing patterns of immigrant settlement in the province over time. Variables included in these data enabled investigation into the impact of a change in social geography (country of birth) and the volume of settlement (annual immigrant landings). As these data were not publically available, one of the challenges to this project was the long period of time between requesting access to these data and receiving permission; this delayed the writing of sections which relied on these data. I was provided the data in a number of spreadsheets for each variable from which I compiled the data on each variable for each CMA. These data are limited as they record the immigrants' intended destination which I will be using as a proxy measure for initial settlement destination. However, I believe this is a reliable indicator as these data are recorded at the time of landing, immediately preceding the settlement period. In the next section I will present my findings. 


\section{Research Findings: Section 4}

This section will focus on these gaps identified in the literature: the volume of immigration to smaller cities in Ontario and the changing socio-demographic characteristics of immigrants within them. I will first explore the general trends that have been seen in the province of Ontario as a whole in the past two decades. My main findings will compare Tiers 4 and 5 in regards to the volumes of immigration they experience and changes of the sociodemographic characteristics of these immigrants from 1996 to 2015. In each section, significant outliers will be identified and further discussed. My findings will be exploratory in nature, provide descriptive statistics, and highlight specific regions which will benefit from further research.

\section{International Migration to Ontario: An Overview 1996 to 2015}

Figure 1: Immigration to Ontario, 2000 to 2015

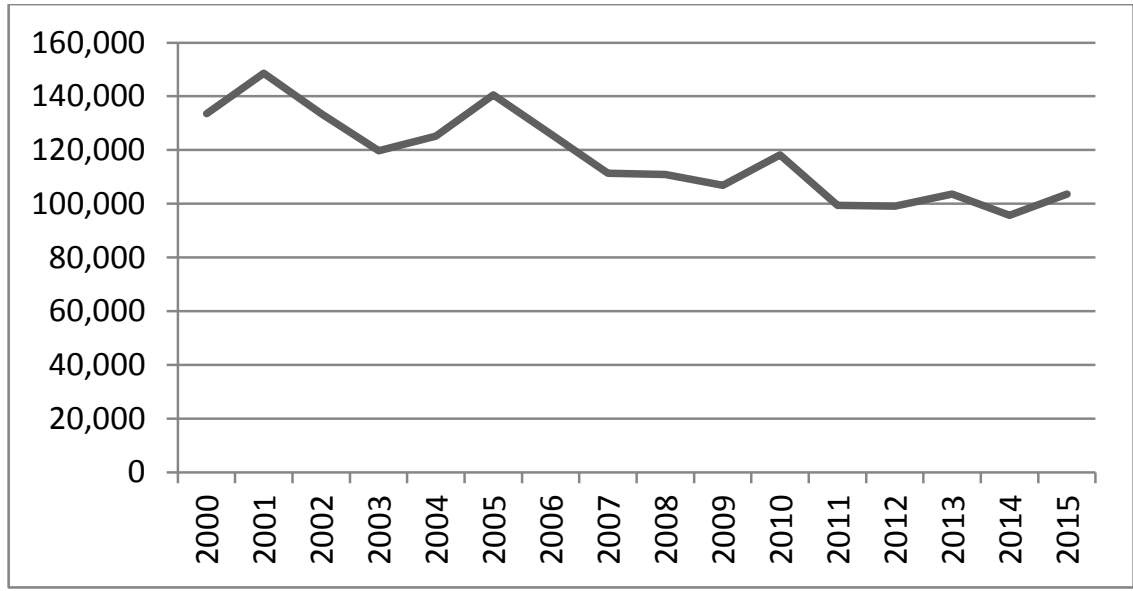

Source: LIDS, IRCC, 2016

Since 1996, the province of Ontario has remained the primary destination for new immigrants to Canada with $43.1 \%$ of recent immigrants ${ }^{8}$ living in Ontario in 2011 (Statistics

\footnotetext{
${ }^{8}$ Recent immigrants are defined in the National Household Survey of 2011 to be those immigrants arriving in the past 5 years, therefore, recent immigrants are those who arrived between 2006 and 2011 (Statistics Canada, 2011).
} 
Canada, 2011). From 2001 to 2015, the total proportion of new permanent residents landing in the province has dropped from 60\% to 38\% of the total Canadian landings (Cappe, 2011; LIDS, 2016). Bonikowska, et al. (2015) have analysed the changing distribution of new immigrants across Canada and have highlighted the movement of these immigrants away from Ontario, due to the development of immigrant selection programs, notably the PNP, and changing regional economic opportunities for new immigrants. These factors were shown to have attracted new immigrants away from Ontario and towards the western provinces, specifically Alberta and Manitoba, over the course of the 2000s (Bonikowska et al., 2015). Figure 1 shows the decline of immigrant landings in the province since 2000. While this declining trend is clear, Ontario has retained its position as the top immigrant destination in Canada with over 103,000 new immigrants indicating their intent to land in Ontario in 2015(LIDS, 2016). The growing attractiveness of Ontario's own PNP and lower oil and gas prices may decrease the ability of the Western provinces to attract as many new immigrants away from Ontario in the future (Bonikowska et al., 2015; Derwing \& Krahn, 2008).

Overall, immigrants entering Ontario through the economic class have declined: annual landings records show that in 2004 economic class immigrants made up 50.9\% of the total immigrants to Ontario declining to $30.8 \%$ in 2014 (CIC, 2014). These data align with what we have previously seen; as economic class immigrants seek economic opportunity they are more likely to be attracted elsewhere by regional economies and immigrant selection programs. Migrants who enter Ontario through the family class are often attracted to the province due to large ethnic communities and by proximity to the sponsoring families. Family class migration may also be to support growth in ethnic networks in smaller cities (Hou, 2007). 
According to the 2011 National Household Survey, the top three source countries of newcomers to Ontario are India (8.6\%), China (7.4\%), and the Philippines (5.6\%). There have been some significant changes in the source regions for Ontario's immigrants since 1996 when immigrants from traditional source countries were more significantly represented. Traditional source countries, such as those in Western and Northern Europe, made up the majority of the total immigrants in Ontario, and across Canada, before the 1970s as discriminatory immigration policies restricted entrance to immigrants from other regions (Statistics Canada, 2013). Two of the top three source regions in 1996, the United Kingdom and Italy, are no longer represented at the top of the list in 2011.With the increasing representation of non-traditional source countries among the top countries of birth for recent immigrants, ethnic diversity in the province is growing.

Figure 2: Visible Minority Population in Toronto and Ontario, 1996 to 2011

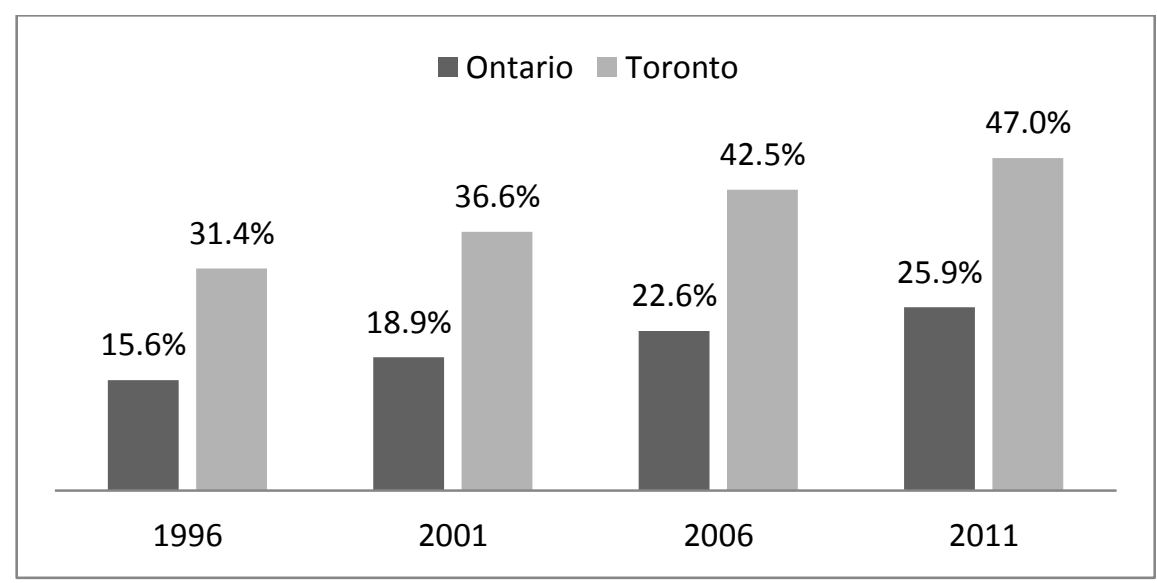

Source: Statistics Canada, 1996, 2001, 2006 and 2011

Data on the visible minority population from the Canadian censuses provides supporting evidence for changing demographics within the province. In $2011,25.9 \%$ of the total population identified as a visible minority, this has increased significantly since 1996 when the proportion 
was 15.6\% (Statistics Canada, 1996; Statistics Canada, 2011). It must be noted that growth in visible minority population is not directly related to immigration, as this growth can alternatively come from reproduction or mobility within Canada, however, according to Statistics Canada (2013), 65.1\% of Canada's visible minority population identified as an immigrant in 2011.

Figure 2 shows the visible minority populations in Toronto and Ontario as a percentage of their respective total populations. This demonstrates that Ontario has seen significant growth in diversity and this increase has been concentrated primarily in Toronto

\section{IA. The Significance of Toronto as a Gateway City}

Since 1996, Toronto has attracted a significant majority of all immigrants to Ontario. It is essential to recognise that trends are not homogenous across the province of Ontario as data on Toronto can skew the results of general trends to reflect its own conditions. Toronto was home to $37.4 \%$ of Canada's total immigrants in 2011 who made up $46.0 \%$ of the total population of the city (Statistics Canada, 2011). In fact, since 70.3\% of Ontario's immigrant population resides in Toronto, provincial trends often reflect the situation of the city to some degree (Statistics Canada, 2011).

Figure 3: Ontario Immigrants who Settle in Toronto, 2000 to 2015

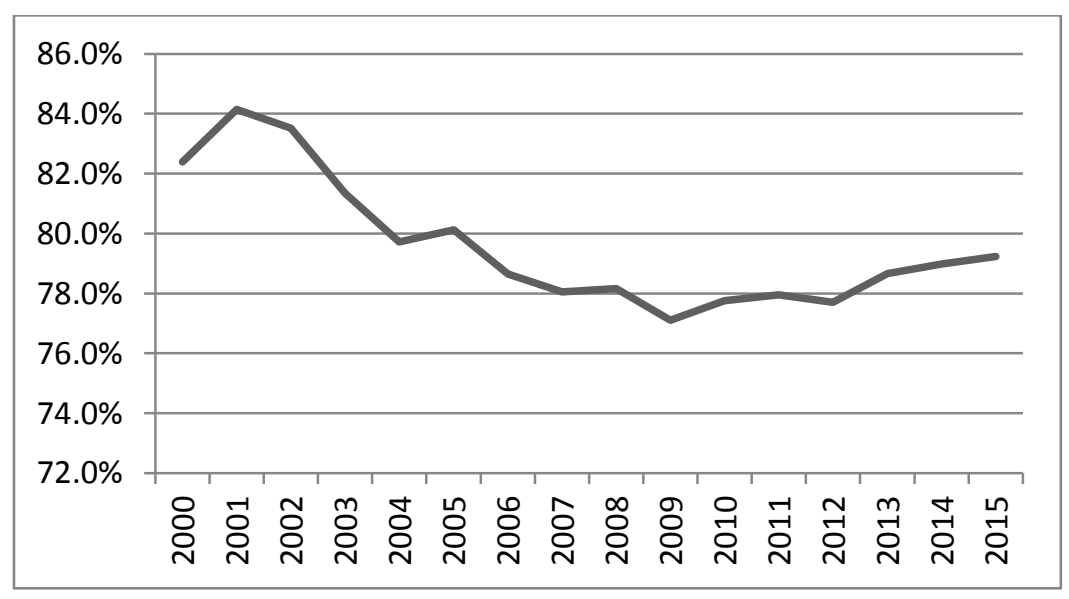

Source: LIDS, IRCC, 2016 
Figure 3 shows the proportion of immigrants to Ontario who chose to settle in Toronto between 2000 and 2015; it is clear that fewer immigrants in Ontario are choosing Toronto. The city has seen the number of immigrants intending to settle in the city each year decline from 110,005 in 2000 to 82,110 in 2015 (LIDS, 2016). This reflects the decrease of new immigrants to Ontario as a whole and the small increase of new immigrants in Ontario settling outside of Toronto. As was discussed in section three, there is a tiered system within the province of Ontario with respect to the size of CMAs and the total number of immigrants who reside in them. In the following two sections, I will attempt to discuss how smaller cities in Ontario have changed as a result of international migration between 1996 and 2015.

\section{The Reality of Regionalization in Ontario}

Figure 4: Growth of Total Populations and Total Immigrant Populations in Tiers 4 and 5, 1996 to 2011

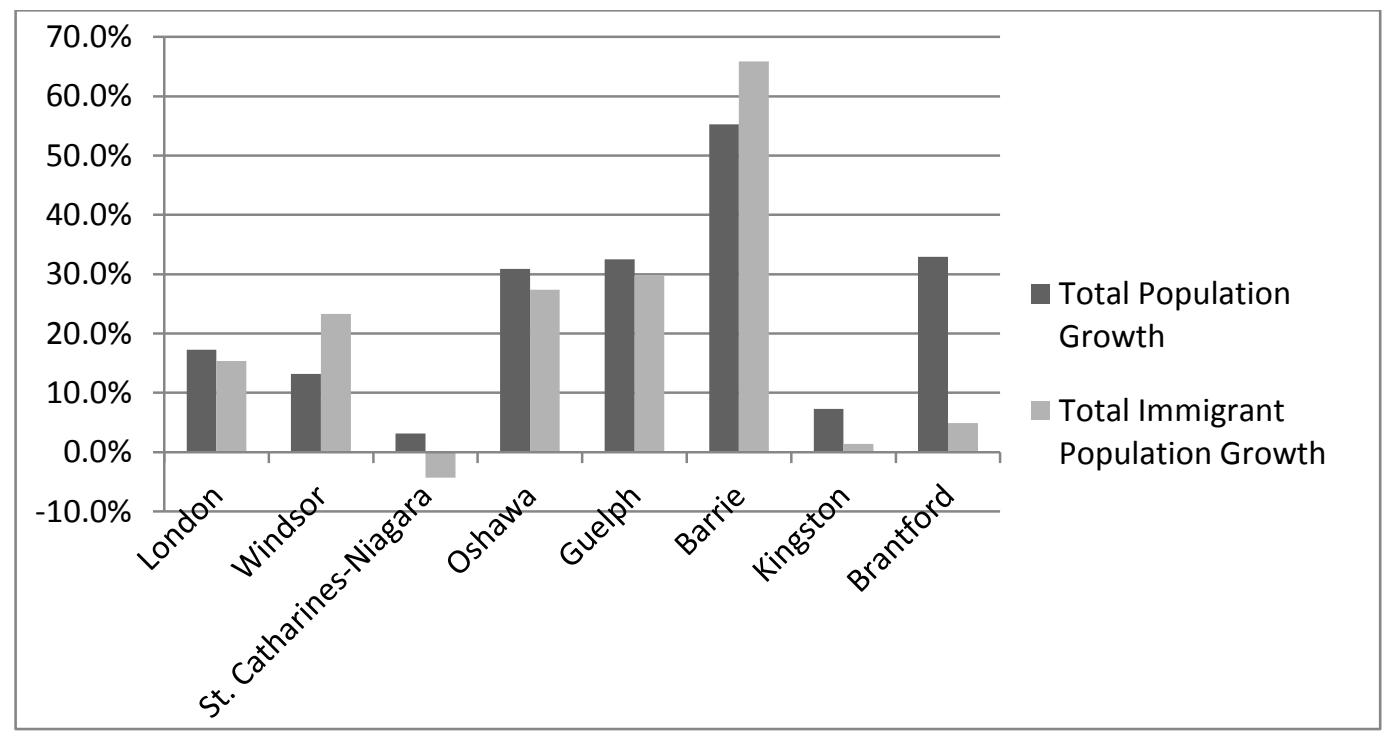

Source: Statistics Canada, 1996 \& 2011

The number of immigrants to Ontario settling into the province's smaller cities has been growing since the early 2000s (LIDS, 2016), gradually increasing the immigrant populations in secondary cities of immigration such as Kitchener-Cambridge-Waterloo, Ottawa, and Hamilton 
(Walton-Roberts, 2011). This increasing share of newcomers settling outside of Toronto seems to point to some degree of success for regionalization policies (Wulff et al., 2008). The following section will look at the volume of settlement into the CMAs in Tiers 4 and 5 to better understand immigration in smaller cities.

\section{IIA. Total Immigrant Population Change from 1996 to 2011}

Table 2: Percentage Immigrant Population in Tiers 4 and 5, 1996 and 2011

\begin{tabular}{|c|c|c|c|c|c|c|}
\hline & \multicolumn{3}{|c|}{1996} & \multicolumn{3}{|c|}{2011} \\
\hline CMAs & $\begin{array}{c}\text { Total } \\
\text { Population }\end{array}$ & $\begin{array}{l}\text { Immigrant } \\
\text { Population }\end{array}$ & $\begin{array}{c}\% \\
\text { Immigrants }\end{array}$ & $\begin{array}{c}\text { Total } \\
\text { Population }\end{array}$ & $\begin{array}{l}\text { Immigrant } \\
\text { Population }\end{array}$ & $\begin{array}{c}\% \\
\text { Immigrants }\end{array}$ \\
\hline \multicolumn{7}{|c|}{ Tier 4} \\
\hline London & 398,616 & 75,975 & $19.1 \%$ & 467,260 & 87,655 & $18.8 \%$ \\
\hline Windsor & 278,685 & 56,990 & $20.4 \%$ & 315,460 & 70,285 & $22.3 \%$ \\
\hline $\begin{array}{c}\text { St. } \\
\text { Catharines- } \\
\text { Niagara }\end{array}$ & 372,406 & 67,285 & $18.1 \%$ & 383,970 & 64,390 & $16.8 \%$ \\
\hline Oshawa & 268,773 & 44,105 & $16.4 \%$ & 351,690 & 56,175 & $16.0 \%$ \\
\hline \multicolumn{7}{|c|}{ Tier 5} \\
\hline Guelph & 105,420 & 21,200 & $20.1 \%$ & 139,670 & 27,515 & $19.7 \%$ \\
\hline Barrie & 118,695 & 13,475 & $11.4 \%$ & 184,325 & 22,350 & $12.1 \%$ \\
\hline Kingston & 143,416 & 17,840 & $12.4 \%$ & 153,900 & 18,090 & $11.8 \%$ \\
\hline Brantford & 100,238 & 14,375 & $14.3 \%$ & 133,250 & 15,080 & $11.3 \%$ \\
\hline
\end{tabular}

Source: Statistics Canada, 1996 \& 2011

The percent changes in total population and total immigrant population Tiers 4 and 5 from 1996 to 2011 are displayed in Table 2; this is based on data from the 1996 Canadian census and 2011 NHS. This table shows there is little consistency in growth across the province. However, there has been general growth across these two tiers since 1996 in both immigrant and total populations. Across Tier 4 the average growth in immigrant populations from 1996 to 2011 was $14.0 \%$, this was slightly lower than the average growth of $15.2 \%$ experienced by the total populations in this tier (LIDS, 2016). Comparatively, Tier 5 displays much more erratic growth; 
this is likely related to the relatively smaller starting points of the populations of this tier in 1996. Tier 5 experienced significantly higher growth than Tier 4 with its total immigrant population rising $24.1 \%$ from 1996 to 2011, slightly slower than its total population, which grew 30.7\% in the same period (LIDS, 2016).

The dissimilarities in growth between the two tiers are likely caused by the larger size of Tier 4 in 1996. The small size of Tier 5 indicates that it would require fewer newcomers to cause such an increase. Hyndman et al., (2006), have also found that the population size of an area strongly correlates with its attractiveness to new immigrants. The positive average growth of both tiers may indicate an increased attractiveness to potential newcomers in 2011 than in 1996. As both tiers see increases in their total immigrant populations it is likely they are developing more established immigrant networks and communities. As the total number of immigrants increases, so does the ability of established immigrants to attract newcomers through chain migration and transnational networks (Croes \& Hooimeijer, 2010; Hyndman et al., 2006).

Table 3: Recent Immigration, 1996 and 2011

\begin{tabular}{|c|c|c|c|c|c|c|}
\hline & \multicolumn{3}{|c|}{1996} & \multicolumn{3}{|c|}{2011} \\
\hline CMAs & $\begin{array}{l}\text { Immigrant } \\
\text { Population }\end{array}$ & $\begin{array}{l}\text { 1991-1996 } \\
\text { Immigrant } \\
\text { Population }\end{array}$ & $\begin{array}{l}\% \text { Recent } \\
\text { Immigrants }\end{array}$ & $\begin{array}{l}\text { Immigrant } \\
\text { Population }\end{array}$ & $\begin{array}{l}2006-2011 \\
\text { Immigrant } \\
\text { Population }\end{array}$ & $\begin{array}{l}\% \text { Recent } \\
\text { Immigrants }\end{array}$ \\
\hline \multicolumn{7}{|c|}{ Tier 4} \\
\hline London & 75,975 & 11,770 & $15.5 \%$ & 87,655 & 11,905 & $13.6 \%$ \\
\hline Windsor & 56,990 & 10,655 & $18.7 \%$ & 70,285 & 9,225 & $13.1 \%$ \\
\hline $\begin{array}{c}\text { St. } \\
\text { Catharines- } \\
\text { Niagara } \\
\end{array}$ & 67,285 & 5,715 & $8.5 \%$ & 64,390 & 5,650 & $8.8 \%$ \\
\hline Oshawa & 44,105 & 3,785 & $8.6 \%$ & 56,175 & 4,080 & $7.3 \%$ \\
\hline \multicolumn{7}{|c|}{ Tier 5} \\
\hline Guelph & 21,200 & 3,660 & $17.3 \%$ & 27,515 & 3,030 & $11.0 \%$ \\
\hline Barrie & 13,475 & 735 & $5.5 \%$ & 22,350 & 2,140 & $9.6 \%$ \\
\hline Kingston & 17,840 & 1,850 & $10.4 \%$ & 18,090 & 1,735 & $9.6 \%$ \\
\hline Brantford & 14,375 & 1,375 & $9.6 \%$ & 15,080 & 990 & $6.6 \%$ \\
\hline
\end{tabular}

Source: Statistics Canada, 1996 \& 2011 
The average total immigrant populations in both tiers also reflect the more established position of Tier 4 in Ontario in terms of international migration. In 2011, the total population of Tier 4 was composed of an average $18.3 \%$ of immigrants (LIDS, 2016). This is higher than the average $13.6 \%$ of immigrants in Tier 5 which was expected due to their relative sizes (LIDS, 2016). In general, the immigrant populations as a proportion of the total populations in both tiers have declined since 1996. This declining percentage may have been caused by the same factors which saw Ontario's share of immigrants decrease. This is supported with the findings of Table 3, which shows the percentage of recent immigrants as a share of the total immigrant population in both 1996 and 2011. This table shows that there were more recent immigrants in 1996 than in 2011 in both tiers, which implies that they have become slightly less attractive as immigrant destinations. With total populations growing more rapidly than their immigrant populations and potential new immigrants being attracted westward as the result of immigrant selection programs and regional economies, a small decline is not unexpected (Bonikowska et al., 2015; Derwing \& Krahn, 2008). The averages discussed in this section are skewed by significant anomalies in both tiers; these will be discussed in the next section.

\section{Total Immigrant Population Change from 1996 to 2011: Significant Outliers}

There is little consistency in the population changes that have been experienced between 1996 and 2011 for individual CMAs. Barrie is the most significant anomaly in Tier 5, with more rapid growth from 1996 to 2011 than any other CMA. The findings of Table 3 support this as Barrie is the only CMA in Tier 5 to see a larger share of recent immigrants in 2011 than in 1996. Research focused on Ontario's smaller communities has supported that the interconnectivity of smaller towns with larger urban centres due to greater transportation networks integrates them into a 'dispersed city' (Everitt \& Gill, 1993, p. 254). While there is no literature on recent 
immigration in Barrie, it can be hypothesized that, due to increased transportation links and rising housing costs in the Greater Toronto Area, Barrie is emerging as such a periphery. Windsor is comparable to Barrie in terms of population growth, immigrant proportion growth and lack of research; however, these similarities are likely to stem from separate causes.

Brantford also emerges in Tier 5 as an anomaly with the population change from 1996 to 2011 reflecting its position at the bottom of this tier as the CMA with the least ability to attract new immigrants. This is despite the fact that Brantford's total population significantly increased. This CMA and surrounding region has been the subject of a number of studies on the provision of settlement services (Sethi, 2013; Sethi, 2015; Wilson-Forsberg, 2015). While these studies do not analyse the reasons why immigrants have chosen to settle in Brantford, they indicate that the regions size and proportionally sizable immigrant population have been recognised as good models for studies on the settlement experiences of newcomers in smaller cities.

Guelph, while experiencing a slight decline in its proportion of immigrants since 1996, emerged as an outlier in Tier 5 for having a relatively larger immigrant population (19.7\%) in 2011 than the average (13.6\%) (Statistics Canada, 1996; Statistics Canada, 2011). The work of Walton-Roberts (2011), on the ability of institutions of higher education to contribute to fostering welcoming and attractive environments for newcomers could be applicable to this CMA due to the presence of the University of Guelph, Ontario Agricultural College and Ontario Veterinary College. It was found that the presence of a university can both attract new immigrants as international students and create an atmosphere where immigrants experience less instances of discrimination (Walton-Roberts, 2011). This research needs to be further assessed for its relevance for individual CMAs, as Table 3 shows that Guelph attracted significantly fewer 
immigrants in the five years preceding 2011 than in those preceding 1996. This indicates that there are likely multiple factors affecting the ability of this CMA to attract newcomers.

\section{IIB. Volume of Settlement in Ontario's Smaller Cities from 2000 to 2015}

Figure 5: Volume of Immigrant Settlement in Tier 4, 2000 to 2015

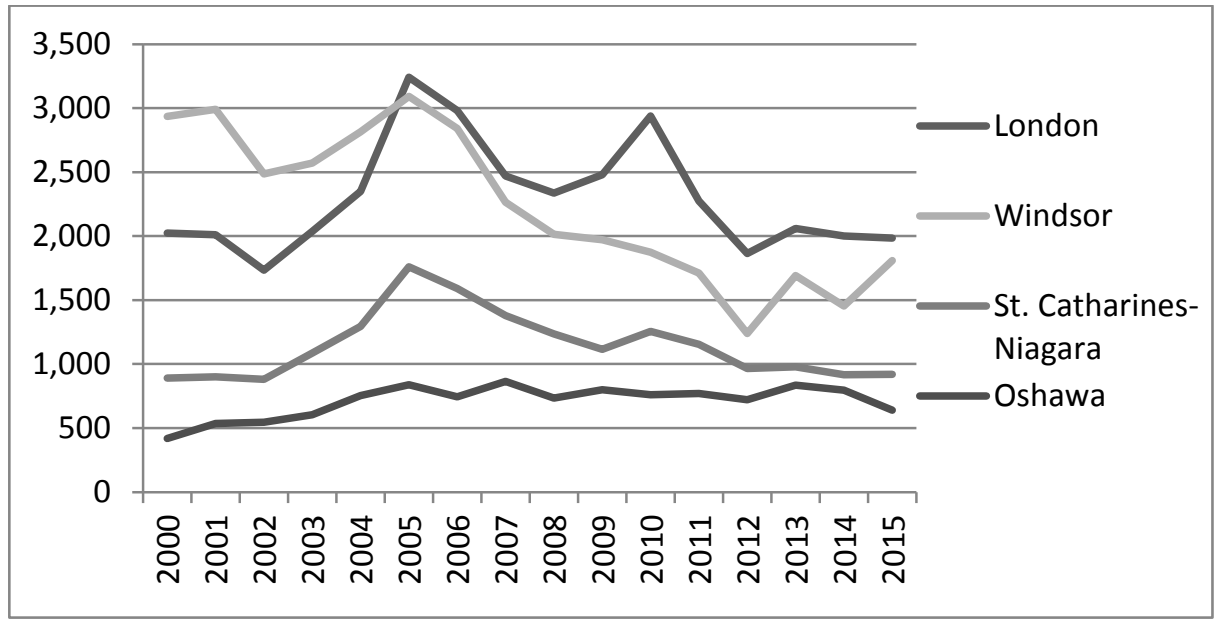

Source: LIDS, IRCC, 2016

Figure 6: Volume of Immigrant Settlement in Tier 5, 2000 to 2015

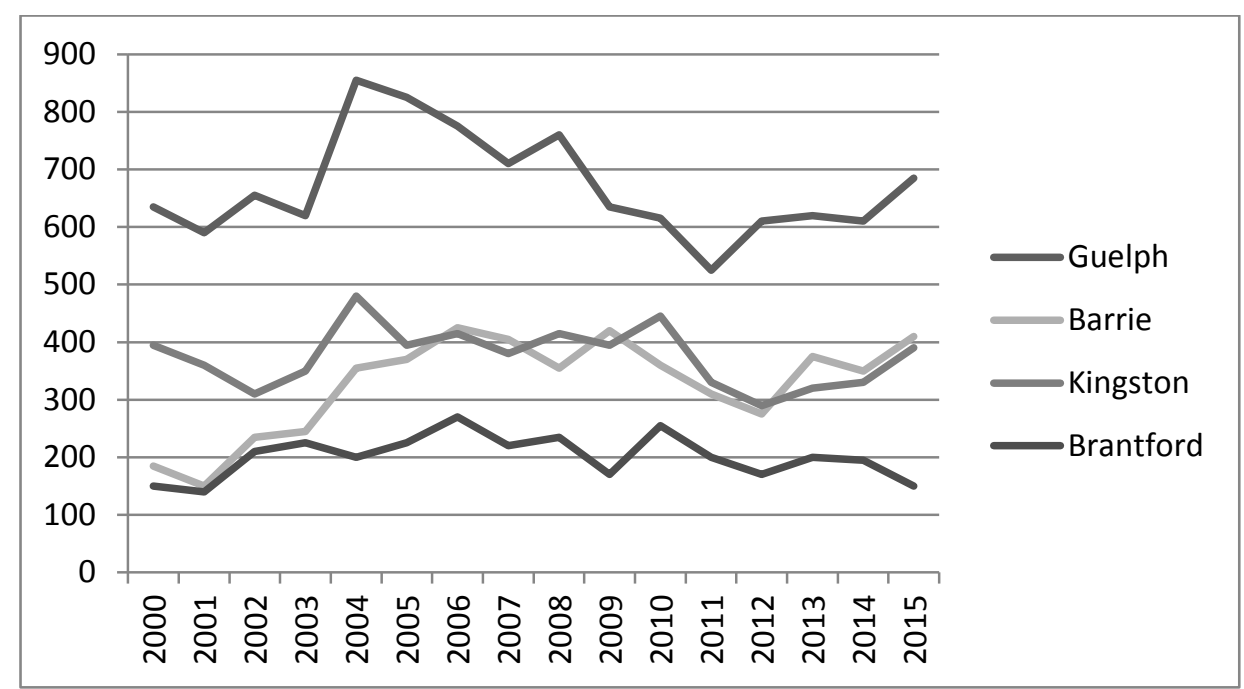

Source: LIDS, IRCC, 2016

The annual volume of settlement from 2000 to 2015 in Tiers 4 and 5 displayed in Figures

5 and 6 show that although most CMAs experienced an increase in landings in the first quarter of the period, this has since stagnated with the total annual landings in 2000 being only slightly 
lower than those in 2015. The figures also show relatively higher numbers of annual landings for Tier 4 as would be expected due to the larger total size and more established immigration history in these CMAs. Figure 5 shows in Tier 4 the average number of landings declined from 1609 in 2001 to 1339 in 2015 (LIDS, 2016). Tier 5 immigrant landings were 310 in 2001 increasing to 409 in 2015 (LIDS, 2016). These changes are fairly insignificant, yet they adequately represent the trends that have emerged through these findings. In general Tier 4 has seen slower growth or stagnation, yet significantly higher number of total immigrants when compared to Tier 5 .

The CMAs in Tier 4 more closely align with the general trend as their annual landings have slowly declined since 2006. This trend was influenced by the attractiveness of regional economies in the Prairie Provinces in the 2000s and the immigrant selection programs which encouraged new immigrants to settle outside of Ontario (Bonikowska et al., 2015; Derwing \& Krahn, 2008). This same trend is apparent in Tier 5. This is likely due to the low number of newcomers who intend to settle in these areas and small size of existing immigrant communities. Large ethnic communities are often cited as one of the primary reasons for newcomers to select certain destinations for settlement (Derwing \& Krahn, 2008; Di Biase \& Bauder, 2005; Hou, 2007). The data have shown in this research that the CMAs in Tier 5 have seen insufficient immigration to develop large ethnic communities. However, it is likely that the numbers of immigrants to Tier 4 have led to the development of emerging immigrant communities. While the outcomes for Tier 4 and 5 CMAs are more encouraging than significant declines, the results are not significant enough to suggest that these tiers have been affected by increased regional immigration. 


\section{$\underline{\text { Volume of Settlement in Ontario's Smaller Cities: Significant Outliers }}$}

Although there is consistency in the immigration patterns of most CMAs when accounting for variations in volume, significant outliers have emerged. Windsor is the only CMA which experienced significant decline in the volume of its annual landings between 2000 and 2015. Although this CMA saw the most annual immigration for the first five years after 2000 when it attracted 2,935 new immigrants, the volume of immigrants began to decline swiftly after 2005 to a low point of 1,240 in 2012; by 2015 this trend had rebounded slightly with 1,810 immigrants intending to settle in Windsor (LIDS, 2016). As Windsor has been considered the 'prototypical automotive manufacturing city-region in Canada' (Irvine, 2014, p.1) it is possible that declining economic conditions in this sector may have been a factor in the overall reduction of landings as immigrants saw fewer economic opportunities in this CMA.

It can be hypothesized that the volume of immigration to Oshawa has also been affected by similar economic conditions in the manufacturing sector as the economy of Oshawa is predominantly based on a declining automotive manufacturing sector (Keenan, 2016). This CMA saw almost no variation in landings between 2000 and 2015, experiencing a 52.4\% change in the volume of immigrants which was largely obscured by more significant variations in the other CMAs of this tier (LIDS, 2016). The perception of limited economic opportunity may have counteracted the expected influence from Oshawa's proximity to Toronto in regards to attracting immigrants (Everden \& Walker, 1993).

Within Tier 5, Guelph represents a relative outlier due to the sheer volume of immigration in comparison to the other CMAs. This high level of settlement indicates that Guelph may be considered a Tier 4 city in the future. The position of Guelph as an emerging 
immigrant destination is supported in a number of studies, such as that conducted by Di Biase and Bauder (2005) which referred to Guelph as a medium-sized city alongside Hamilton and London in the context of the representation of immigrants in the population. In this regard, we have seen that Guelph may belong among a higher tier, yet its historic total immigrant population implies that this placement is relatively new and requires further development to establish considerable immigrant networks.

The data that we have seen thus far have not provided evidence for recent regionalization among the smaller cities in Ontario. As more immigrants have settled outside of Toronto within Ontario the immigrant populations and annual landings in smaller cities have not generally shown significant increase or decline since 2000. This indicates that many factors are affecting the volume of immigrant settlement in Ontario's smaller cities. The next section will further explore patterns of settlement in the province to determine how the demographic trends in the smaller cities may have changed between 1996 and 2015.

\section{Evidence of Growing Diversity}

Historically, immigration to Canada has been fairly homogenous with the majority of new immigrants arriving before the 1970s coming from traditional source countries. Before the 1970s these immigrants were openly preferred and immigrants from many other source regions were restricted from coming to Canada (Kelley \& Trebilcock, 2010) ${ }^{9}$. While this changed after the 1970s with the introduction of immigrant selection policies based on skills and human capital rather than source region, these changes have been much quicker to affect the immigrant

\footnotetext{
${ }^{9}$ Before the 1970's immigrant selection policy was openly discriminatory towards immigrants who originated outside of Europe, this changed with the introduction of the Immigration Act in 1976 which established a points system to select newcomers based on their economic potential and human capital factors, this was intended to remove overt discrimination from the immigration selection system (Kelley \& Trebilcock, 2010).
} 
populations of larger urban centres such as Toronto than smaller cities (Statistics Canada, 2013).

It has been found that immigrants from non-traditional source regions ${ }^{10}$ are more likely to settle in gateway cities and immigrants from traditional source regions are more comfortable settling outside of these urban centres (Everitt \& Gill, 1993; Matthews \& Satzewich, 2006).

In this section I will be assessing the extent to which the source regions for immigrants to Ontario's smaller cities have changed from 1996 to 2015. This will reveal whether the CMAs in Tiers 4 and 5 have become more ethno-culturally diverse since 1996. I will be discussing this diversity vis-à-vis the variables of country of birth and total visible minority population as a percentage of total immigrant population. I will first discuss the general trends that emerge from Tiers 4 and 5; next I will identify if any CMAs present as outliers within the two tiers.

IIIA. Top Countries of Birth from 2010 to 2015

Table 4: Top Three Countries of Birth for Tier 4, 2001 to 2015

\begin{tabular}{|c|c|c|c|c|c|c|c|c|c|c|}
\hline & CMA & Rank & 2001 & & 2006 & & 2011 & & 2015 & \\
\hline \multirow{12}{*}{$\begin{array}{c}\text { Country } \\
\text { of Birth } \\
\text { Tier } 4\end{array}$} & \multirow{3}{*}{ London } & 1 & China & 170 & Columbia & 635 & Columbia & 290 & Syria & 195 \\
\hline & & 2 & Columbia & 145 & China & 230 & Iraq & 225 & Iraq & 165 \\
\hline & & 3 & India & 135 & USA & 185 & China & 130 & Philippines & 135 \\
\hline & \multirow{3}{*}{ Oshawa } & 1 & U.K, & 45 & India & 90 & Philippines & 85 & Philippines & 160 \\
\hline & & 2 & USA & 45 & Pakistan & 55 & India & 65 & Jamaica & 55 \\
\hline & & 3 & India & 40 & China & 55 & USA & 60 & India & 50 \\
\hline & \multirow{3}{*}{$\begin{array}{c}\text { St. } \\
\text { Catharines- } \\
\text { Niagara }\end{array}$} & 1 & USA & 95 & Columbia & 315 & USA & 120 & Philippines & 155 \\
\hline & & 2 & Sudan & 55 & USA & 155 & Philippines & 110 & China & 90 \\
\hline & & 3 & U.K. & 55 & China & 110 & China & 90 & USA & 75 \\
\hline & \multirow{3}{*}{ Windsor } & 1 & China & 390 & India & 410 & Iraq & 355 & Iraq & 335 \\
\hline & & 2 & India & 390 & USA & 290 & USA & 160 & Syria & 305 \\
\hline & & 3 & Pakistan & 230 & China & 280 & India & 135 & Philippines & 130 \\
\hline
\end{tabular}

Source: LIDS, IRCC, 2016

\footnotetext{
${ }^{10}$ Traditional source countries represent countries with a long history of sending immigrants to Canada. They include the U.K., US, and Northern and Western European Countries (Kelley \& Trebilcock, 2010).
} 
The top three newcomer countries of birth for each CMA in Tier 4 are represented in Table 4 across four periods of time, 2001, 2006, 2011 and 2015. The results from this tier seem to reflect the general trends present in both Toronto and Ontario as a whole until 2006. In all of these regions, immigrants born in India and China are present in the majority of CMAs in 2001 and 2006. After 2006, the results of Tier 4 share fewer similarities with the general trends seen across the province. The addition of Syria and Iraq in the top three source countries for Tier 4 show the high representation of refugees who indicated they would be settling in Tier 4 in 2011 and 2015. It is likely that government assisted refugees are settled ${ }^{11}$ in some of the CMAs in Tier 4, both in attempting to achieve a greater regional dispersal of refugees across the province and because these emerging immigrant destinations likely have basic support services available for the refugees ( CIC, 2001; Krahn et al., 2005). The representation of refugees outside of major immigrant gateways will likely continue as the Canadian government looks to sponsor greater numbers of refugees and disperse them across the country (Johnson, 2016).

Table 5 displays the top three countries of birth for newcomers to Tier 5 in 2001, 2006, 2011, and 2015. When compared to Tier 4, Tier 5 displays results that are more closely aligned with the general trends in Toronto and Ontario. As opposed to Tier 4, these findings emerge after 2006 for the CMAs in Tier 5, as in 2001 the presence of several traditional source countries shows that more diverse immigrants were slower to settle outside of large urban centres (CIC, 2001). From 2006 to 2015 the majority of CMAs in Tier 5 display similar results to as Ontario, with India, China, and the Philippines being strongly represented. It must be noted that many of the top countries of birth in Tier 5 are shown with extremely small numbers of immigrants, this

\footnotetext{
${ }^{11}$ Government assisted refugees are settled in designated cities which can support the settlement of these refugees through Resettlement Assistance Programs. In Ontario, these designated cities are: Hamilton, Kitchener, Ottawa, Toronto, Mississauga, London, Windsor, and Peterborough (CIC, 2016)
} 
makes it much more challenging to determine if the results are representational. However, it is clear that the pool of newly landed immigrants is extremely diverse across all of the CMAs in Tier 5. An average of 16.5 countries of birth is represented in each CMA in 2015, not including those countries which were declared by less than five individuals (LIDS, 2016).

Table 5: Top Three Countries of Birth for Tier 5, 2001 to 2015

\begin{tabular}{|c|c|c|c|c|c|c|c|c|c|c|}
\hline & CMAs & Rank & \multicolumn{2}{|l|}{2001} & \multicolumn{2}{|l|}{2006} & \multicolumn{2}{|l|}{2011} & \multicolumn{2}{|l|}{2015} \\
\hline \multirow{12}{*}{$\begin{array}{c}\text { Country } \\
\text { of Birth } \\
\text { Tier } 5\end{array}$} & \multirow{3}{*}{ Barrie } & 1 & USA & 20 & Pakistan & 45 & Philippines & 35 & Philippines & 100 \\
\hline & & 2 & U.K. & 15 & USA & 35 & U.K. & 35 & India & 45 \\
\hline & & 3 & Germany & 10 & Philippines & 30 & Pakistan & 25 & U.K. & 30 \\
\hline & \multirow{3}{*}{ Brantford } & 1 & India & 25 & India & 40 & India & 25 & India & 25 \\
\hline & & 2 & China & 10 & USA & 35 & Philippines & 20 & Philippines & 15 \\
\hline & & 3 & Poland & 10 & Philippines & 15 & U.K. & 15 & USA & 10 \\
\hline & \multirow{3}{*}{ Guelph } & 1 & India & 90 & India & 125 & India & 70 & Philippines & 245 \\
\hline & & 2 & China & 65 & China & 70 & Philippines & 60 & India & 70 \\
\hline & & 3 & Afghanistan & 60 & Philippines & 70 & China & 45 & China & 40 \\
\hline & \multirow{3}{*}{ Kingston } & 1 & China & 80 & China & 80 & China & 35 & Philippines & 65 \\
\hline & & 2 & India & 35 & USA & 35 & USA & 35 & China & 35 \\
\hline & & 3 & Pakistan & 25 & Iran & 30 & Philippines & 30 & India & 35 \\
\hline
\end{tabular}

Source: LIDS, IRCC, 2016

Many of the top countries of birth across Ontario (i.e. India, China, and the Philippines), are seen in the top counties of birth in Tier 5, and to a lesser extent, Tier 4, due to the significant migration history and sheer volume of immigrants originating from these countries. It is possible that, due to this large volume, immigrant networks may have developed outside of the large urban centres. The development of communities which circumvent Toronto has been discussed in reference to Filipino immigrants in smaller cities (Lusis \& Bauder, 2008). These communities can attract additional immigrants through chain migration and the development of transnational networks (Croes \& Hooimeijer, 2010). 
Table 6: Recent Immigrants by Country of Birth, 2011

\begin{tabular}{|c|c|c|c|c|c|c|c|}
\hline \multicolumn{7}{|c|}{ Tier 4 } \\
\hline \multicolumn{2}{|c|}{ London } & \multicolumn{2}{c|}{ Oshawa } & \multicolumn{2}{c|}{$\begin{array}{c}\text { St. Catharines- } \\
\text { Niagara }\end{array}$} & \multicolumn{2}{c|}{ Windsor } \\
\hline Colombia & 2,020 & Philippines & 445 & USA & 755 & USA & 1,565 \\
\hline China & 765 & UK & 405 & Philippines & 550 & Iraq & 1,195 \\
\hline USA & 740 & India & 390 & Colombia & 465 & China & 560 \\
\hline \multicolumn{7}{|c|}{ Tier 5 } \\
\hline Barrie & Brantford & Guelph & Kingston \\
\hline UK & 360 & India & 200 & India & 330 & USA & 180 \\
\hline India & 205 & USA & 120 & Philippines & 305 & China & 170 \\
\hline South Korea & 205 & Philippines & 95 & UK & 260 & India & 160 \\
\hline
\end{tabular}

Source: Statistics Canada, 2011

The findings of Tables 4 and 5 are further supported by Table 6 which shows the top three countries of birth for recent immigrants in both tiers based on the 2011 NHS. These countries are reflective of the findings from the 2006 landings records. This indicates that, although the landings records only display the intended initial destination of new immigrants, they are fairly representative of the reality of settlement. This supports the idea that many new immigrants do settle in their intended destinations and significant secondary migration is not seen to an extent that would discount the use of annual landings records. In general, across Tiers 4 and 5, those immigrants who make up the majority of landings in 2006 are represented in the top countries of birth in the 2011 NHS.

\section{Top Countries of Birth: Significant Outliers}

The development of a Colombian community can be seen to emerge from the landings data on London, Ontario in Tier 4. The number of immigrants who indicated that they intended to settle in London and who were born in Colombia far out numbers those from any other source country represented in this CMA in 2006. This is further supported by the position of Colombia as the top country of birth for recent immigrants to London in the 2011 NHS as seen in Table 6 . 
This continuity suggests that London is retaining the majority of newcomers from Colombia over time. This is an example of the way ethnic communities are developed over time through established immigrants who 'pioneer' new immigrant destinations (Croes \& Hooimeijer, 2010). Chain migration may be responsible for the development of immigrant communities like those seen with the Colombian community in London. Large numbers of new immigrants are following those who are already established as they receive information on emerging communities in smaller cities through transnational networks (Lusis \& Bauder, 2008). The Colombian community in London has been the subject of a limited amount of research (see Pozniak, 2009; Rush, Ng, Irwin, Stitt, \& He, 2007); however, they present a unique opportunity to study the growth patterns of an emergent ethnic community in a smaller city in Ontario.

Amongst the CMAs in Tier 4, Windsor also stands out for having a large number of immigrants from the United States intending to settle in this region from 2001 to 2011 . While the US is represented in many CMAs, primarily in Southern Ontario, the highest levels of immigrants from the US are present in Windsor. This is not surprising due to the proximity of this CMA to the US-Canada border. As we saw in the previous section, immigrants from traditional source countries may be more comfortable settling outside of major immigrant destinations (CIC, 2001). Additionally, immigrants from the United States have been referred to as 'invisible immigrants' due to their ability to quickly integrate, both socially and economically, in Canada (Matthews \& Satzewich, 2011). These three factors make Windsor an extremely attractive destination for immigrants from the United States and this pattern of settlement is unlikely to change in the coming decades.

Within Tier 5, Barrie has experienced the most significant change across the period. Immigrants intending to settle in this CMA originated primarily in traditional source countries in 
2001, but since 2006, immigration to Barrie has been similar to that of Ontario and Toronto with the Philippines and India sending the most international migrants to this region. This information, in conjunction with the data in the previous section which described the rapid growth of Barrie's immigrant population and total population, suggests that Barrie has become more interconnected with Toronto in the past decade. As Toronto's city limits stretch further, it is possible that Barrie is becoming part of its 'dispersed city' with a reliance on the agglomeration economy in the urban centre (Everitt \& Gill, 1993). The position of Barrie within Ontario's transportation system, connected to Toronto via a major freeway, enhances its ability to develop an economic relationship with the larger city (Sweet et al., 2016). This integral connection indicates that new immigrants seeking proximity to the gateway city, but also affordable housing may chose Barrie as an alternative in a similar way that immigrant settlement patterns have shifted to the peripheries of large cities into the suburbs (Bunting \& Filion, 1999; Evenden \& Walker, 1993).

\section{IIIB. Change in Visible Minority Populations from 1996 to 2011}

The share of visible minority population in 1996 and 2011 is represented in Table 7 for all CMAs in Tiers 4 and 5 along with the percent change over time. Across Tier 4 , the average growth in visible minority population was $114.6 \%$ (Statistics Canada, 1996; Statistics Canada, 2011). This provides supporting evidence for the growing diversity found in the previous section where traditional source countries saw less representation in smaller cities after 2006. When compared with Tier 5, the finding suggests that Tier 4 underwent more consistent growth in all across the CMAs. 
Table 7: Percent Share and Percent Change in Visible Minority Populations for Tiers 4 and 5, 1996 to 2011

\begin{tabular}{|c|c|c|c|c|c|c|c|}
\hline & \multicolumn{3}{|c|}{1996} & \multicolumn{4}{|c|}{2011} \\
\hline CMAs & Population & $\begin{array}{l}\text { Visible } \\
\text { Minority } \\
\text { Population } \\
\end{array}$ & $\begin{array}{l}\% \\
\text { Share }\end{array}$ & Population & $\begin{array}{l}\text { Visible } \\
\text { Minority } \\
\text { Population } \\
\end{array}$ & $\begin{array}{l}\% \\
\text { Share }\end{array}$ & $\begin{array}{l}\% \\
\text { Change }\end{array}$ \\
\hline \multicolumn{8}{|c|}{ Tier 4} \\
\hline London & 398,616 & 30,325 & $7.6 \%$ & 467,260 & 61,040 & $13.1 \%$ & $101.3 \%$ \\
\hline Windsor & 278,685 & 27,615 & $9.9 \%$ & 315,460 & 54,250 & $17.2 \%$ & $96.5 \%$ \\
\hline $\begin{array}{l}\text { St. } \\
\text { Catharines- } \\
\text { Niagara }\end{array}$ & 372,406 & 13,445 & $3.6 \%$ & 383,970 & 27,010 & $7.0 \%$ & $100.9 \%$ \\
\hline Oshawa & 268,773 & 16,035 & $6.0 \%$ & 351,690 & 41,620 & $11.8 \%$ & $159.6 \%$ \\
\hline \multicolumn{8}{|c|}{ Tier 5} \\
\hline Guelph & 105,420 & 8,340 & $7.9 \%$ & 139,670 & 19,565 & $14.0 \%$ & $134.6 \%$ \\
\hline Barrie & 118,695 & 3,085 & $2.6 \%$ & 184,325 & 11,780 & $6.4 \%$ & $281.8 \%$ \\
\hline Kingston & 143,416 & 6,250 & $4.4 \%$ & 153,900 & 9,325 & $6.1 \%$ & $49.2 \%$ \\
\hline Brantford & 100,238 & 4,245 & $4.2 \%$ & 133,250 & 7,485 & $5.6 \%$ & $76.3 \%$ \\
\hline
\end{tabular}

Source: Statistics Canada, 1996 \& 2011

Overall, Tier 5 has a significantly smaller visible minority population than Tier 4 . This was expected as research suggests that new immigrants are less attracted to centres with smaller population sizes (Hyndman et al., 2006). The average visible minority community in this Tier grew to $8.0 \%$ in 2011 from $4.8 \%$ in 1996 (Statistics Canada, 1996; Statistics Canada, 2011). The results of Tier 5 are skewed by internal discrepancies within the tier, likely because newcomers are likely to choose a migration destination where they have social ties or have found potential economic opportunities (Derwing \& Krahn, 2008; Hyndman et al., 2006; Lusis \& Bauder, 2008). Even with recent trends changing the common source countries of new immigrants, it will take time before more diverse countries are represented in significant numbers in the smaller cities.

Change in Visible Minority Populations: Significant Outliers

The outliers found in this section are difficult to discuss in isolation visible minority immigrants are likely to be affected by the same factors which dictate the volume of settlement 
in each of these CMAS. This is particularly valid as an increasing proportion of Ontario's total immigrants belong to visible minority groups (Bonikowska et al., 2015; CIC, 2001). The significant outliers that have emerged from the results of changing visible minority settlement are therefore those that experienced variances in total immigrant population and total visible minority population growth.

Within Tier 4, Oshawa has the fastest growing visible minority population since 1996. It is possible that the proximity of Oshawa to the gateway city of Toronto has influenced the rapid development of a visible minority community (Everden \& Walker, 1993). This proximity may increase the attractiveness of Oshawa to newcomers as they can benefit from both the resources and amenities in Toronto and the more affordable cost of living outside of the major metropolitan centre (Everitt \& Gill, 1993). The low level of annual landings seen earlier in this paper by Oshawa indicates that among these landings a significant proportion identify as a visible minority. It is also possible that Oshawa is experiencing the results of outmigration of visible minority individuals from other regions. While non-traditional source countries are represented in the composition of many of new immigrants to Oshawa, the numbers are too low to support the first possibility alone. Therefore, it is likely that some of the visible minority population in Oshawa has relocated, likely from within Toronto through secondary migration. Oshawa has been identified in a few exploratory pieces as a future immigrant destination to watch, although any further research has yet to be seen (Donaldson, 2006; Radford, 2007).

Kingston has the smallest proportional visible minority community of any of the CMAs in both Tiers with its change in growth (86.3\%) between 1996 and 2011lower than that of the average for Tier 5. This is not surprising as this paper has not identified significant settlement in Kingston. These results indicate that this CMA has been unable to attract significant new 
patterns of immigrant settlement from non- traditional source countries. The demographics of immigrants in Kingston have not been addressed in the literature. However, the research of Walton-Roberts (2011) would have led me to hypothesize that this CMA would see more significant growth due to its large educational institutions and the role these types of institutions have been seen to have on attracting and retaining new immigrants. Preliminary evidence suggests otherwise.

The most significant finding in either tier was seen in the development of a small visible minority community in Barrie. This CMA presents a significant anomaly in regards to the rapid change in the size of its visible minority population from 1996 to 2011 which has nearly tripled. It could be considered that this high percentage is a reflection of the extremely low visible minority population in this CMA in 1996 and the evolving relationship between Barrie and Toronto that was discussed earlier in this paper (Everitt \& Gill, 1993; Sweet et al., 2016). Both Barrie and Oshawa have presented trends that reflect the general patterns of settlement in the large urban centre and it has been suggested that these regions may have become part of a greater ‘dispersed city’ (Everitt \& Gill, 1993, p. 254). The development of significant transportation infrastructure, through rapid public transportation and freeways, has served to further connect the economies of these regions (Sweet et al., 2016). It is possible that these regions are becoming the new periphery and will experience greater settlement in the future due to the costs of living within the city centre (Everden \& Walker, 1993), however, further research is needed to support this trend. 


\section{Conclusion: Section 5}

This paper has addressed the regionalization of international migration in Canada as immigrant settlement has been encouraged towards new destinations. The focus of this paper was on the impact of this trend on the smaller cities in Ontario. Firstly, the Literature Review brought together the limited literature on regionalization in Canada particularly in regards to the reasons why immigrants choose smaller cities and how smaller cities attract new immigrants. Most significantly, this section highlighted the key factors that influence immigrants who chose to settle in smaller cities: the presence of close friends and family and potential economic opportunities. The research shows that strong social ties can play a more significant role in the attraction of immigrants, while economic opportunities can support retention (Di Biase \& Bauder, 2005). This section also demonstrated the role of immigration programs in facilitating the settlement of new immigrants and the importance of pre-migration information relevant to smaller cities (Carter et al., 2008; Lusis \& Bauder, 2008) It was also suggested that settlement services in smaller cities can provide services additional to language training to improve the initial settlement experience of newcomers, especially since new immigrants face significant challenges in this period (Depner \& Teixeira, 2012; Wang \& Trulove, 2003).

Secondly, in Research Design and Methods a tiered system of Ontario’s CMAs was developed as the literature review yielded no consistent categorization scheme. In order to facilitate comparisons of similar small cities this system was created based on the total immigrant populations of each CMA. This enabled two tiers of CMAs with small and emerging immigrant populations to be selected and compared based on the volume of immigrant settlement and changing social geography from 1996 to 2015. 
Thirdly, in Research Findings, I found a general trend of significantly increased settlement into Ontario's smaller cities since 1996 has not emerged; however, major changes in the socio-demographic characteristics of recent immigrants have been found that support the development of new immigrant pathways. Visible minority immigrants have been known for their preference of settling in large urban centres with significant co-ethnic communities (Statistics Canada, 2013). The findings of my paper suggest higher proportions of visible minority immigrants are choosing to settle in smaller cities since 2006. This may lead to greater future settlement in these regions as pathways for chain migration develop. Therefore, this paper suggests a broader perspective of regionalization to one that considers new immigrant pathways and their ability to increase the attractiveness of smaller cities for immigrants from changing source countries in the context of Ontario. Comparisons of the Tier 4 and 5 CMAs have shown that while this trend is more likely to affect the relatively larger CMAs in Tier 4, outliers such as Barrie may also develop new immigrant pathways due to their place in the periphery of the gateway city of Toronto.

Immigration trends are constantly evolving (Kelley \& Trebilcock, 2010). The two factors considered most responsible for attracting new Canadian immigrants westward over the course of the 2000s (Provincial Nominee Programs and labour market shortages in Alberta) are unlikely to have the same effect on immigration in the coming decade (Derwing \& Krahn, 2008). As these factors change, it is possible that new immigrants will return in higher proportions to the province of Ontario. Nevertheless, as the immigration programs and economic opportunities available in Canada are unlikely to remain constant, the findings from the literature review of this paper suggest that smaller cities themselves can play a role in attracting new immigrants and supporting their settlement in order to retain and develop new immigrant communities to 
advance their economic and cultural growth. The final section of this paper will discuss the avenues for further research that have arisen from my findings and explain why they were outside of the scope of this project.

\section{$\underline{\text { Limitations in Scope and Avenues of Future Research }}$}

Due to the exploratory nature of this paper, several significant gaps that arose from the literature review were unable to be included for further analysis in my research. This paper was also constrained by length and available time which resulted in the elimination of a number of sections which were considered in the early stages of this project. This limitation of time restricted my ability to fully connect my research findings with the existing Canadian literature on the topic of regionalization. An analysis of the municipal initiatives specific to immigration in each of the smaller cities in Tiers 4 and 5 exceeded the scope of this project; however, understanding these initiatives and related services available for new immigrants would have illuminated the extent to which municipalities are taking an active role in the attraction and retention of newcomers.

Due to limitations with the isolation of data on economic class immigrants, I was unable to further explore the impact of immigrant selection programs, which value high human capital, on the characteristics of those immigrants who settle in smaller cities. With further data, the variables of education qualification and knowledge of an official language could be used to evaluate how these programs are reflected in the human capital of new economic immigrants in Ontario's smaller cities.

Finally, an area in need of significant scholarly attention arose as a result of the findings of this paper. Although there has been limited literature considering the reasons why immigrants chose to settle in smaller cities (Derwing \& Krahn, 2008; Lusis \& Bauder, 2008), none of these 
approach this topic from the position of the immigrant in the pre-migration decision-making period. As such, it will be necessary to conduct further research to better understand how these decisions are made when potential migrants are still in their countries of origin and what information they access in regards to smaller cities before they arrive in Canada. Each of these topics are deserving of their own reviews and require significant future research. 


\section{Bibliography}

Baker, J., Price, J., \& Walsh, K. (2016). Unwelcoming communities: youth observations of racism in St. John's, Newfoundland and Labrador, Canada. Journal of Youth Studies, 19(1), 103-116.

Bonikowska, A., Hou, F., \& Picot, G. (2015). Changes in the Regional Distribution of New Immigrants to Canada. Statistics Canada.

Bunting, T., \& Filion, P. (1999). Dispersed City Form in Canada: The Kitchener CMA Case Example. The Canadian Geographer, 43(3), 268-287.

Cappe, M. (2011). Starting on Solid Ground: The municipal role in immigrant settlement. Federation of Canadian Municipalities.

Carter, T., Morrish, M., \& Amoyaw, B. (2008). Attracting Immigrants to Smaller Urban and Rural Communities: Lessons Learned from the Manitoba Provincial Nominee Program. Journal of International Migration and Integration, 9(2), 161-183.

Carter, T., Pandey, M., \& Townsend, J. (2010). The Manitoba Provincial Nominee Program: Attraction, Integration and Retention of Immigrants. Montreal: Institute for Research on Public Policy.

Chadwick, K., \& Collins, P. (2015). Examining the relationship between social support availability, urban center size, and self-perceived mental health of recent immigrants to Canada: A mixed-methods analysis. Social Science \& Medicine, 128, 220-230.

Citizenship and Immigration Canada. (2001). Towards a More Balanced Geographic Distribution of Immigrants.

Citizenship and Immigration Canada. (2016, August 25). Map of destination communities and service provider organizations. Retrieved from Government of Canada: http://www.cic.gc.ca/english/refugees/welcome/map.asp

Citizenship and Immigration Canada. (2011). Evaluation of the Provincial Nominee Program. Ottawa: Citizenship and Immigration Canada.

Citizenship and Immigration Canada. (2014). Facts and figures 2014 - Immigration overview: Permanent residents. Government of Canada.

Croes, H., \& Hooimeijer, P. (2010). Gender and Chain Migration: The Case of Aruba. Population, Space and Place, 16, 121-134.

Da, W.W. (2010). Support Networking Strategies of Female Chinese Immigrants in London, Ontario. Asian and Pacific Migration Journal, 19(4), 525-549.

Depner, W., \& Teixeira, C. (2012). Welcoming Communities? An Assessment of Community Services in Attracting and Retaining Immigrants in the South Okanagan Valley (British Columbia, Canada) with Policy Recommendations. Journal of Rural and Community Development, 7(2), 72-97. 
Derwing, T., \& Krahn, H. (2008). Attracting and Retaining Immigrants Outside the Metropolis: is the pie too small for everyone to have a piece? The case of Edmonton, Alberta. Journal of International Migration and Integration, 9, 185-202.

Di Biase, S., \& Bauder, H. (2005). Immigrant Settlement in Ontario: Location and Local Labour Markets. Canadian Ethnic Studies, 37(3), 114-135.

Donaldson, I. (2006). Visible Minority Demographic Projections and Multicultural Integration in Canada's Urban Areas. Our Diverse Cities, 2, 146-153.

Everden, L., \& Walker, G. (1993). From Periphery to Center: The Changing Geography of the Suburbs. In L. Bourne, \& D. Ley, The Changing Social Geography of Canadian Cities (pp. 234-251). Montreal: McGill-Queen's University Press.

Everitt, J., \& Gill, A. (1993). The Social Geography of Small Towns. In L. Bourne, \& D. Ley, The Changing Social Geography of Canadian Cities (pp. 252-266). Montreal: McGillQueen's University Press.

Federation of Canadian Municipalities. (2008). Quality of Life in Canadian Communities: Immigration and Diversity in Canadian Cities and Communities.

Ferrer, A., Picot, G., \& Riddell, W. (2014). New Directions in Immigration Policy: Canada's Evolving Approach to the Selection of Economic Immigrants. International Migration Review, 48(3), 846-867.

Frideres, J. (2006). Cities and Immigrant Integration: The future of second- and third-Tier centers. Our Diverse Cities, 2, 3-8.

Ghosh, S. (2014). A Passage to Canada: The Differential Migrations of South Asian Skilled Workers. Journal of International Migration and Integration, 15(4), 715-735.

Hou, F. (2007). Changes in the Initial Destinations and Redistribution of Canada's Major Immigrant Groups: Reexamining the Role of Group Affinity. International Migration Review, 41(3), 680-705.

Hyndman, J., Schuurman, N., \& Fiedler, R. (2006). Size Matters: Attracting New Immigrants to Canadian Cities. Journal of International Migration and Integration, 7(1), 1-25.

Immigration, Refugees, and Citizenship Canada. (2016). Permanent Resident Landed Immigrant Database.

Irvine, D. (2014). Local and Regional Labour Market Trends in the Canadian Automotive Manufacturing Industry. Automotive Policy Research Center.

Johnson, L. (2016, August 17). Canada wants more Chinese workers, students and tourists, says immigration minister. Retrieved from CBCnews: http://www.cbc.ca/news/canada/britishcolumbia/chinese-immigration-canada-china-1.3725202 
Keenan, G. (2016, September 2). Trouble in Canada's Motor City: The future of GM's Oshawa plant hangs in the balance. Retrieved from The Globe and Mail: http://www.theglobeandmail.com/report-on-business/industry-news/despite-fall-inproduction-closing-gm-plant-would-be-a-blow-to-oshawa/article31696750/

Kelley, N., \& Trebilcock, M. (2010). The Making of the Mosaic: A History of Canadian Immigration Policy. Toronto: University of Toronto Press.

Krahn, H., Derwing, T., \& Abu-Laban, B. (2005). The Retention of Newcomers in Second- and Third- Tier Canadian Cities. International Migration Review, 39(4), 872-894.

Ley, D., \& Tutchener, J. (2001). Immigration, Globalisation and House Prices in. Housing Studies, 16(2), 199-223.

Lichter, D. (2012). Immigration and the New Racial Diversity in Rural America. Rural Sociology, 77(1), 3-35.

Lo, L., \& Teixeira, C. (2015). Immigrants Doing Business in a Mid-sized Canadian City: Challenges, Opportunities, and Local Strategies in Kelowna, British Columbia. Growth and Change, 46(4), 631-653.

Lund, D., \& Hira-Friesen, P. (2013). Measuring the welcoming capacities of host urban and rural communities. Canadian Ethnic Studies, 45(3), 65-80.

Lusis, T., \& Bauder, H. (2008). " Provincial" Immigrants: The Social, Economic, and Transnational Experiences of the Filipino Canadian Community in Three Ontario Second-Tier Cities. Toronto: CERIS- The Ontario Metropolis Center.

Matthews, K., \& Satzewich, V. (2006). The Invisible Transnationals? Americans in Canada. In V. Satzewich, \& L. Wong, Transnational Identities and Practices in Canada (pp. 164179). Vancouver: UBC Press.

Office of the Auditor General of Ontario. (2014). Ministry of Citizenship and Immigration: Provincial Nominee Program. In 2014 Annual Report of the Office of the Auditor General of Ontario (pp. 289-331). Toronto: Queen's Printer for Ontario.

Olson, S., \& Kobayashi, A. (1993). The Emerging Ethnocultural Mosaic. In L. Bourne, \& D. Ley, The Changing Social Geography of Canadian Cities (pp. 138-152). Montreal: McGill-Queen's University Press.

Pozniak, K. (2009). Talking the "Immigrant Talk": Immigration Narratives and Identity Construction among Colombian Newcomers. Canadian Ethnic Studies, 41(1), 173-190.

Radford, P. (2007). A Call for Greater Research on Immigration Outside of Canada's Three Largest Cities. Our Diverse Cities, 2, 47-51.

Ray, B., \& Preston, V. (2013). Experiences of discrimination and discomfort: A comparison of metropolitan and non-metropolitan locations. The Canadian Geographer, 57(2), 233-254. 
Rush, T. J., Ng, V., Irwin, J. D., Stitt, L. W., \& He, M. (2007). Food Insecurity and Dietary Intake of Immigrant Food Bank Users. Canadian Journal of Dietetic Practice and Research, 68(2), 73-78.

Sethi, B. (2013). Newcomers Health in Brantford and the Counties of Brant, Haldimand and Norfolk: Perspectives of Newcomers and Service Providers. Journal of Immigrant and Minority Health, 15(5), 925-931.

Sethi, B. (2015). Education and Employment Training Supports for Newcomers to Canada's Middle-sized Urban/Rural Regions: Implications for social work practice. Journal of Social Work, 15(2), 138-161.

Statistics Canada. (1996). Census of Canada. Statistics Canada Catalogue no. 95F0182XDB. Ottawa, Ontario.

Statistics Canada. (2001). Census of Canada. Statistics Canada Catalogue no. 93F0053X. Ottawa, Ontario.

Statistics Canada. (2006). Census of Canada. Statistics Canada Catalogue no. 92-591-X. Ottawa, Ontario.

Statistics Canada. (2011). National Household Survey. Statistics Canada Catalogue no. 99-004XWE. Ottawa, Ontario.

Statistics Canada. (2012). Census Dictionary: Census year, 2011. Ottawa: Minister of Industry.

Statistics Canada. (2013). Immigration and Ethnocultural Diversity in Canada, National Household Survey, 2011. Ottawa: Minister of Industry.

Sweet, M., Bullivant, B., \& Kanaroglou, P. (2016). Are Major Canadian City-Regions Monocentric, Polycentric, or Dispersed? Urban Geography, 1-27.

Teixeira, C. (2009). New immigrant settlement in a mid-sized city: a case study of housing barriers and coping strategies in Kelowna, British Columbia. The Canadian Geographer, 53(3), 323-339.

Trempe, R. (1997). Not Just Numbers: a Canadian framework for future immigration. Ottawa: Citizenship and Immigration Canada.

Troper, H. (2003). Becoming an Immigrant City: A History of Immigration into Toronto since the Second World War. In P. Anisef, \& M. Lanphier, The World in a City (pp. 19-62). Toronto: University of Toronto Press.

Voyer, A. (2015). Multiculturalism as the Normative Context of Immigrant Reception: Somali Immigrant Inclusion in Lewiston, Maine. Journal of Intercultural Studies, 36(5), 544563.

Walton-Roberts, M. (2007). Immigration regionalization in Ontario: policies, practices and realities. Our Diverse Cities, 4, 13-19. 
Walton-Roberts, M. (2011). Immigration, the university and the welcoming second Tier city. Journal of International Migration and Integration, 12(4), 453-473.

Wang, S., \& Trulove, M. (2003). Evaluation of Settlement Services Programs for Newcomers in Ontario: A Geographical Perspective. Journal of International Migration and Integration, 4, 577-606.

Wilson-Forsberg, S. (2015). “We Don't Integrate; We Adapt:” Latin American Immigrants Interpret Their Canadian Employment Experiences in Southwestern Ontario. Journal of International Migration and Integration, 16(3), 469.

Winders, J. (2012). Seeing immigrants institutional visibility and immigrant incorporation in new immigrant destinations. The ANNALS of the American Academy of Political and Social Science, 641(1), 58-78.

Wulff, M., Carter, T., Vineberg, R., \& Ward, S. (2008). Attracting New Arrivals to Smaller Cities and Rural Communities: Findings from Australia, Canada and New Zealand. International Migration and Integration, 9(2), 119-124. 